\title{
FINAL PROJECT REPOIRT
}

\section{Project Title: \\ Control of Coal Combustion $\mathrm{SO}_{2}$ and $\mathrm{NO}_{x}$ Emissions by In-Boiler Injection of CMA.}

DOE Grant \#: DE-FG22-92PC92535

\author{
Principal Investigator: Yiannis A. Levendis \\ Graduate Students: Judi Steciak and Ajay Atal \\ Department of Mechanical Engineering, 334 Snell \\ Northeastern University, Boston, MA 02115
}

Consultant: Girard Simons.

Project Performance Period: 1 July 1992 - 31 December 1994

\section{DISCLAIMER}

This report was prepared as an account of work sponsored by an agency of the United States Government. Neither the United States Government nor any agency thereof, nor any of their employees, makes any warranty, express or implied, or assumes any legal liability or responsibility for the accuracy, completeness, or usefulness of any information, apparatus, product, or process disclosed, or represents that its use would not infringe privately owned rights. Reference herein to any specific commercial product, process, or service by trade name, trademark, manufacturer, or otherwise does not necessarily constitute or imply its endorsement, recommendation, or favoring by the United States Government or any agency thereof. The views and opinions of authors expressed herein do not necessarily state or reflect those of the United States Government or any agency thereof.

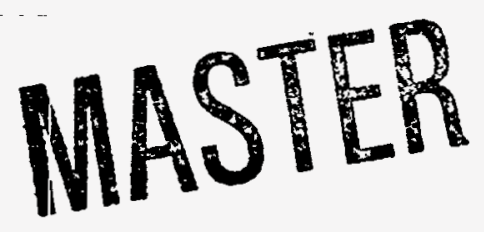




\section{DISCLAIMER}

Portions of this document may be illegible in electronic image products. Images are produced from the best available original document. 


\section{Project Objectives:}

The principal objectives of this research were two-fold: (A) To understand the mechanism and assess the effectiveness of sulfur capture by the chemical calcium magnesium acetate (CMA); and (B) To evaluate the $\mathrm{NO}_{x}$ reduction capabilities of CMA by pyrolyzing its organic constituent (the acetate) and, thereby, reducing NO to stable $\mathrm{N}_{2}$. The optimum conditions and the location of CMA introduction in the furnace were to be identified.

To achieve these goals water solutions of CMA or dry powders of CMA were injected into hot air or gases simulating the furnace exhaust (containing $\mathrm{SO}_{x}, \mathrm{NO}_{x}, \mathrm{CO}_{2}, \mathrm{H}_{2} \mathrm{O}, \mathrm{O}_{2}$ etc.) and the composition of gaseous and solid products of the reaction was monitored. The processes of burning the organic acetate as well as the calcination, sintering and sulfation of the remaining solids were studied.

The effectiveness of samples of "homemade" CMA, containing various amounts of calcium and magnesium, was investigated to explore the role of these two chemicals in the $\mathrm{NO}_{x}$ and, mainly, in the $\mathrm{SO}_{2}$ capture processes.

Finally, CMA was introduced in the matrix of coal particles by an ion exchange technique. Upon subsequent combustion, the $\mathrm{SO}_{2}-\mathrm{NO}_{x}$ emissions were monitored and compared to those from burning untreated coal. The composition and physical structure of the ash residues was examined. Both techniques (CMA pretreatment and CMA injection) may commercially be implemented, either separate or simultaneously. Finally, apart of CMA, the effectiveness of other carboxylic salts of calcium: calcium formate (CF), calcium acetate (CA), calcium propanate (CP) and calcium benzoate (CB) to capture $\mathrm{SO}_{2}$ and $\mathrm{NO}_{x}$ emissions, in the post-flame region of the furnace, was assessed.

\section{Executive Summary of Contents.}

A brief summary of the contents of each chapter in this report is given on page 10 , in the section Outline of the Present Work. 


\section{Overall Abstract}

A study was conducted to determine the efficacy of carboxylic calcium and magnesium salts (e.g., calcium magnesium acetate or CMA, $\left.\mathrm{Ca} \mathrm{Mg}_{2}\left(\mathrm{CH}_{2} \mathrm{COOH}\right)_{6}\right)$ for the simultaneous removal of $\mathrm{SO}_{2}$ and $\mathrm{NO}_{x}$ in oxygenlean atmospheres. Experiments were performed in a high-temperature furnace that simulated the post-flame environment of a coal-fired boiler by providing similar temperatures and partial pressures of $\mathrm{SO}_{2}, \mathrm{NO}_{x}, \mathrm{CO}_{2}$ and $\mathrm{O}_{2}$.

When injected into a hot environment, the salts calcined and formed highly porous "popcorn"-like cenospheres. Residual $\mathrm{MgO}$ and/or $\mathrm{CaCO}_{3}$ and $\mathrm{CaO}$ reacted heterogeneously with $\mathrm{SO}_{2}$ to form $\mathrm{MgSO}_{4}$ and/or $\mathrm{CaCO}_{4}$. The organic components - which can be manufactured from wastes such as sewage sludge - gasified and reduced $\mathrm{NO}_{x}$ to $\mathrm{N}_{2}$ efficiently if the atmosphere was moderately fuel-rich.

Dry-injected CMA particles at a $\mathrm{Ca} / \mathrm{S}$ ratio of 2 , residence time of 1 second and bulk equivalence ratio of 1.3 removed over $90 \%$ of $\mathrm{SO}_{2}$ and $\mathrm{NO}_{x}$ at gas temperatures $\geq 950^{\circ} \mathrm{C}$. When the furnace isothermal zone was $\leq 950^{\circ} \mathrm{C}, \mathrm{Ca}$ was essentially inert in the furnace quenching zone, while $\mathrm{Mg}$ continued to sorb $\mathrm{SO}_{2}$ as the gas temperature cooled at a rate of $-130^{\circ} \mathrm{C} / \mathrm{sec}$. Hence, the removal of $\mathrm{SO}_{2}$ by CMA could continue for nearly the entire residence time of emissions in the exhaust stream of a power plant.

The composition of the calcined salts was used to interpret the results of a cenosphere sulfation model. The sulfation kinetics of $\mathrm{Ca}$-containing calcined residues were found to be bounded by those of pure $\mathrm{CaO}$ and pure $\mathrm{CaCO}_{3}$.

The high solubility of the salts makes them excellent candidates for wet injection. Fine mists of CMA sprayed in the furnace at temperatures between 850 and $1050^{\circ} \mathrm{C}$, removed $90 \%$ of $\mathrm{SO}_{2}$ at a $\mathrm{Ca} / \mathrm{S}$ molar ratio of 1 , about half of the amount used in the dry injection experiments to achieve a similar $\mathrm{SO}_{2}$ reduction. The $\mathrm{NO}_{x}$ reduction chemistry was not affected by water when $\mathrm{CMA}$ was sprayed at a $\mathrm{Ca} / \mathrm{S}$ ratio of 1 , i.e., the same reduction efficiency was achieved as with dry injection $(25-30 \%)$.

Additional research is needed to improve the efficiency and reduce the cost of the relatively expensive carboxylic acid salts as dual $\mathrm{SO}_{2}-\mathrm{NO}_{x}$ reduction agents. For example, wet injection of the salts could be combined with less expensive hydrocarbons such as lignite or even polymers such as poly(ethylene) that could be extracted from the municipal waste stream. 


\section{List of Publications}

1. "The Effectiveness of Calcium Magnesium Acetate (CMA) as an $\mathrm{SO}_{x}$ Sorbent in Coal Combustion" Yiannis A. Levendis, Wenqi Zhu, Donald L. Wise and Girard A. Simons. AIChE Journal, 63 (7), 3608, 1993.

2. "Removal of $\mathrm{SO}_{2}$ by Reaction with Calcium Magnesium Acetate: Comparison of Sulfation Model and Experiment" Judith Steciak, Yiannis A. Levendis and Girard Simons. Presented at the Tenth Annual International Pittsburgh Coal Conference, Pittsburgh, PA, September 20-24, 1993.

3. "The Removal of $\mathrm{SO}_{2}$ by Calcium Magnesium Acetate of Different $\mathrm{Ca}$ to $\mathrm{Mg}$ Ratios" Judith Steciak and Yiannis A. Levendis. Presented at the Technical Meeting of the Eastern Sections of the Combustion Institute, Princeton University, Princeton, NJ, October 25-27, 1993.

4. "Calcium Magnesium Acetate (CMA) as an $\mathrm{NO}_{x}$ Reduction Agent in Coal Combustion." J. Steciak, W. Zhu, Y.A. Levendis and D.L. Wise, Presented at the Joint Technical Meeting of the Central and Eastern Sections of the Combustion Institute, New Orleans, LA, March 15-17, 1993.

5. "Combustion and $\mathrm{SO}_{2}-\mathrm{NO}_{x}$ Emissions of Bituminous Coal Particles Treated with CMA" Ajay Atal, Judi Steciak and Yiannis A. Levendis. Fuel, accepted for publication. 1994.

6. "The Effectiveness of Calcium (Magnesium) Acetate and Calcium Benzoate as $\mathrm{NO}_{x}$ Reduction Agents in Coal Combustion." Judith Steciak, Yiannis A. Levendis and Donald L. Wise. Combustion Science and Technology, in the press, 1994.

7. "The Effectiveness of Calcium Magnesium Acetate as a Dual $\mathrm{SO}_{2}-\mathrm{NO}_{x}$ Emission Control Agent" Judith Steciak, Yiannis A. Levendis and Donald L. Wise, AIChE Journal accepted for publication, 1994. 
8. "Dual $\mathrm{SO}_{2}-\mathrm{NO}_{x}$ Concentration Reduction by Calcium Salts of Carboxylic Acids" Judith Steciak, Yiannis A. Levendis, Donald L. Wise and Gerard. Journal of Environmental Engineering, accepted for publication, 1994.

9. Wise, D.L., Levendis, Y.A. and Metghalchi, M., co-editors, CMA: An Emerging Bulk Chemical for Multipurpose Environmental Applications, Elsevier Scientific Publishers, the Netherlands, 1991.

Drs. Wise and Levendis have also organized an "International Symposium on Uses of CMA", held at Northeastern University, on 16-19 May, 1991.

Two US Patents have also been issued:

1. "Method of Simultaneously Removing $\mathrm{SO}_{2}$ and $\mathrm{NO}_{x}$ Pollutants from Exhaust of a Combustion System." U.S. Patent No. 5,312,605, 1994.

2. "Use of Aromatic Salts for Simultaneously Removing $\mathrm{SO}_{2}$ and $\mathrm{NO}_{x}$ Pollutants from Exhaust of a Combustion System." U.S. Patent No. 5,352,423, 1994. 


\section{Table of Contents}

Title, Project Objectives

page

Executive Summary

ii

Overall Abstract

iii

List of Publications

iv

Table of Contents

vi

List of Tables

$\mathrm{x}$

List of Figures

xii

Chapter 1. Overall Introduction

References

Chapter 2. The Effectiveness of Calcium (Magnesium) Acetate and Calcium

Benzoate as $\mathrm{NO}_{x}$ Reduction Agents in Coal Combustion

References

47

Chapter 3. The Effectiveness of Calcium Magnesium Acetate as a Dual $\mathrm{SO}_{2}$ $\mathrm{NO}_{x}$ Emission Control Agent

References

Chapter 4. Dual $\mathrm{SO}_{2}-\mathrm{NO}_{x}$ Reduction by Fine Mists of CMA

References

Chapter 5. Dual $\mathrm{SO}_{2}-\mathrm{NO}_{x}$ Reduction by Calcium Salts of Carboxylic

Acids

References 
Chapter 6. Custom-Blended Secondary Fuel and Sorbent Injection for Dual $\mathrm{SO}_{2}-\mathrm{NO}_{x}$ Emission Control 183 References

Chapter 8. Overall Summary

Appendix I. Combustion and $\mathrm{SO}_{2}-\mathrm{NO}_{x}$ Emissions of Bituminous Coal Particles Treated with CMA 207

References

Appendix II. Determination of the Bulk Equivalence Ratio, $\phi$ 246

Appendix III. Chemical Thermodynamics and Chemical Kinetics Calculations 


\section{List of Tables}

Table 2.I Bulk Equivalence Ratio, $\phi$

Table 2.II Residue Colors

Table 2.III Possible NO Reduction Reactions, Equilibrium Constants and Reaction Rate Constants at $1130^{\circ} \mathrm{C}$

Table 2.IV Possible Reactions Involving the Phenyl Radical Equilibrium Constants and Reaction Rate Constants at $1130^{\circ} \mathrm{C}$

Table 3.I Nominal vs. Actual Mole Percentage of Ca

Table 3.II $\mathrm{SO}_{2}$ Reduction in the Isothermal Zone and in the Post-Furnace Zone

Table 3.III Relative Contribution of $\mathrm{Ca}$ and $\mathrm{Mg}$ in $\mathrm{CMA}$ to $\mathrm{SO}_{2}$ Reduction in the Isothermal Zone

Table 3.IV $\mathrm{Ca}$ and $\mathrm{Mg}$ Utilization in the Isothermal Zone

Table 3.V XRD Analysis of Sulfated CMA Residues

Table 4.I Dual $\mathrm{SO}_{2}-\mathrm{NO}_{x}$ Reduction at Gas Temperatures near $1050^{\circ} \mathrm{C}$

Table 5.I Physical Characteristics of Sorbents after Calcination at $950^{\circ} \mathrm{C}$

Table 5.II Effect of Afterfire Air on $\mathrm{SO}_{2} / \mathrm{NO}_{x}$ Reduction

Table 5.III Mass Percentages of $\mathrm{CaCO}_{3}$ and $\mathrm{CaO}$ in Calcined CP

Table 5.IV Kinetic Data for Sulfation Reactions

Table 5.V Calculated Apparent Shell Density and Porosity 
Table 6.I $\mathrm{SO}_{2}-\mathrm{NO}_{x}$ Reduction by $\mathrm{CP}$ and Lignite at $1050^{\circ} \mathrm{C}$

Table 6.II $\mathrm{SO}_{2}-\mathrm{NO}_{x}$ Reduction by $\mathrm{CF}$ and Sucrose at $1000^{\circ} \mathrm{C}$

Table 6.III $\mathrm{SO}_{2}-\mathrm{NO}_{x}$ Reduction bf $\mathrm{CF}$ and Poly(ethylene)

Table I.I Properties of the Coals Used

Table I.II Physical Properties of the PSOC-1451 Coal and Char

Table I.III Emissions of $\mathrm{SO}_{2}$ and $\mathrm{NO}_{x}$ from Pulverized Coal 


\section{List of Figures}

Figure 1.1 A schematic of staged combustion for $\mathrm{NO}_{x}$ control in a pulverized coal boiler. Courtesy of Mitsubishi Heavy Industries, LTD.

Figure 1.2 A Schematic of post-combustion injection of secondary fuel in a coal-fired boiler. Courtesy of Mitsubishi Heavy Industries, LTD.

Figure 2.1 High Temperature Furnace, Particle Fluidizer, Pyrometer and Gas Monitoring System

Figure 2.2 Residues from NO Reduction Experiments With Calcium Magnesium Acetate and $500 \mathrm{ppm}$ NO
a. Unreacted, $53-63 \mu \mathrm{m}$
b. $750^{\circ} \mathrm{C}, 0 \% \mathrm{O}_{2}$
c. $950^{\circ} \mathrm{C}, 0 \% \mathrm{O}_{2}$
d. $1150{ }^{\circ} \mathrm{C}, 0 \% \mathrm{O}_{2}$
e. $750{ }^{\circ} \mathrm{C}, 2 \% \mathrm{O}_{2}$
f. $1150{ }^{\circ} \mathrm{C}, 2 \% \mathrm{O}_{2}$
g. $750{ }^{\circ} \mathrm{C}, 5 \% \mathrm{O}_{2}$
h. $1150{ }^{\circ} \mathrm{C}, 5 \% \mathrm{O}_{2}$

Figure 2.3 NO Reduction by CMA at various gas temperatures, o- - - o $0 \% \mathrm{O}_{2} ; \mathrm{x}-\mathrm{x} 2 \% \mathrm{O}_{2} ; *-\cdot-\cdot * 5 \% \mathrm{O}_{2}$

Figure 2.4 NO Reduction by $\mathrm{CA}$ at various gas temperatures, $0---00 \%$ $\mathrm{O}_{2} ; \mathrm{x}-\mathrm{x} 2 \% \mathrm{O}_{2} ; *-\cdot-\cdot * 5 \% \mathrm{O}_{2}$ 28

Figure 2.5 NO Reduction by $\mathrm{CB}$ at various gas temperatures, $0---00 \%$ $\mathrm{O}_{2} ; \mathrm{x}-\mathrm{x} 2 \% \mathrm{O}_{2} ; *-\cdot-\cdot * 5 \% \mathrm{O}_{2}$

Figure 2.6 Calcium Benzoate Combustion in Reduced Oxygen. a) Combustion Intensity in $5 \% \mathrm{O}_{2}$. b) Combustion Temperature in $5 \% \mathrm{O}_{2}$. c) 
Combustion Intensity in $2 \% \mathrm{O}_{2}$. d) Combustion Temperature in $2 \% \mathrm{O}_{2}$.

Figure 2.7 $\mathrm{NO}_{x}$ reduction (\%) or $\mathrm{NH}_{3}$ concentration (ppm) as a function of gas temperature. Data from both the isothermal and afterfire air zones.

Figure 2.8 Threshold of $\mathrm{NH}_{3}$ formation in isothermal and afterfire air zones. Bulk $\phi$ of isothermal zone at which $5 \mathrm{ppm} \mathrm{NH}_{3}$ was detected vs. gas temperature.

Figure 3.1 SEM of calcined CMA. Porosity $=0.70, \mathrm{BET}=25-30 \mathrm{~m}^{2} / \mathrm{g}$ when calcined at $950^{\circ} \mathrm{C}$.

Figure 3.2 SEM of calcined CMA particle cracked open to reveal interior voids and pore structure.

Figure 3.3 Schematic of the high temperature furnace, particle fluidizer, and gas monitoring system.

Figure 3.4 Typical temperature-time histories of sorbents from entry into the isothermal zone (time 0 ), to exit from the isothermal zone and entry into the post-furnace $-130^{\circ} \mathrm{C} / \mathrm{sec}$. quenching zone (at about $4.5 \mathrm{sec}$; this was also the point where the nitrogen-quenched water-cooled quenching probe was inserted).

64

Figure 3.5 TGA profiles for CMA, CA and MA. Heating rate was $20^{\circ} \mathrm{C} / \mathrm{min}$. Rate of mass loss in in $\mathrm{mg} / \mathrm{s}$.

Figure 3.6 $\mathrm{SO}_{2}$ and $\mathrm{NO}_{x}$ reduction by $\mathrm{CMA}$ as a function of temperature at $\mathrm{Ca} / \mathrm{S}=2((\mathrm{Ca}+\mathrm{Mg}) / \mathrm{S}=6)$ in atmospheres containing $12 \% \mathrm{CO}_{2}, 3 \% \mathrm{O}_{2}$, $2000 \mathrm{ppm} \mathrm{SO} \mathrm{S}_{2}$ and $1000 \mathrm{ppm}$ NO. $1 \mathrm{~s}$ residence time. o - $\mathrm{SO}_{2}$ reduction; $\mathrm{x}-\mathrm{NO}_{x}$ reduction. a) Without after-fire air; b) With after-fire air. 67 
Figure 3.7 $\mathrm{SO}_{2}$ and $\mathrm{NO}_{x}$ reduction by CMA as a function of temperature at $\mathrm{Ca} / \mathrm{S}=2((\mathrm{Ca}+\mathrm{Mg}) / \mathrm{S}=6)$ in atmospheres containing $3 \% \mathrm{O}_{2}, 2000 \mathrm{ppm}$ $\mathrm{SO}_{2}$ and $1000 \mathrm{ppm}$ N.O. o $-\mathrm{SO}_{2}$ reduction at 4 to 5 sec. residence time; * $-\mathrm{SO}_{2}$ reduction at 2 to 3 sec. residence time; $\mathrm{x}-\mathrm{NO}_{x}$ reduction at 2 to 3 sec. residence time.

Figure 3.8 $\mathrm{SO}_{2}$ and $\mathrm{NO}_{x}$ reduction by $\mathrm{CA}$ as a function of temperature at $\mathrm{Ca} / \mathrm{S}=2$ in atmospheres containing $3 \% \mathrm{O}_{2}, 2000 \mathrm{ppm} \mathrm{SO}_{2}$ and $1000 \mathrm{ppm}$ NO. o - $\mathrm{SO}_{2}$ reduction; $\mathrm{x}-\mathrm{NO}_{x}$ reduction. Nominal furnace residence time varied between 4 to $5 \mathrm{sec}$.

Figure 3.9 $\mathrm{SO}_{2}$ and $\mathrm{NO}_{x}$ reduction by $\mathrm{MA}$ as a function of temperature at $\mathrm{Mg} / \mathrm{S}=4$ in atmospheres containing $3 \% \mathrm{O}_{2}, 2000 \mathrm{ppm} \mathrm{SO}_{2}$ and $1000 \mathrm{ppm}$ NO. o - $\mathrm{SO}_{2}$ reduction; $\mathrm{x}-\mathrm{NO}_{x}$ reduction. Nominal furnace residence time varied between 4 to $5 \mathrm{sec}$.

Figure 3.10 $\mathrm{SO}_{2}$ and $\mathrm{NO}_{x}$ reduction by CMA with different Ca-to-Mg molar ratios at a temperature of $950^{\circ} \mathrm{C}$ in atmospheres containing $3 \% \mathrm{O}_{2}, 2000$ ppm $\mathrm{SO}_{2}$ and $1000 \mathrm{ppm}$ NO. $100 \% \mathrm{Ca}$ corresponds to calcium acetate, $0 \% \mathrm{Ca}$ is $100 \% \mathrm{Mg}$ or magnesium acetate, and commercial CMA is about $30 \%$ Ca. o - $\mathrm{SO}_{2}$ reduction; $\mathrm{x}-\mathrm{NO}_{x}$ reduction.

Figure 3.11 $\mathrm{SO}_{2}$ reduction by rapidly quenched reactions as a function of temperature with $\mathrm{Ca} / \mathrm{S}=2$ or $\mathrm{Mg} / \mathrm{S}=4$ in atmospheres containing $3 \% \mathrm{O}_{2}$, $2000 \mathrm{ppm} \mathrm{SO}_{2}$ and $1000 \mathrm{ppm}$ NO. o - CMA; * $\mathrm{CA} ;-$ - MA. Nominal furnace residence time varied between 4 to 5 sec. $\mathrm{NO}_{x}$ reduction was not affected by quenching.

Figure 4.1 Experimental apparatus.

Figure 4.2 SEM photograph of sprayed CMA sulfated at $750^{\circ} \mathrm{C}$. Low magnification 
Figure 4.3 SEM photograph of sprayed CMA sulfated at $750^{\circ} \mathrm{C}$. High magnification. Note cenospheres with extremely thin, porous walls. 103

Figure 4.4 SEM photograph of sprayed CF sulfated at $1050^{\circ} \mathrm{C}$. Low magnification.

Figure 4.5 SEM photograph of sprayed CF sulfated at $1050^{\circ} \mathrm{C}$. High magnification.

Figure 4.6 SEM photograph of sprayed CA sulfated at $1050^{\circ} \mathrm{C}$. Low magnification.

Figure 4.7 SEM photograph of sprayed CA sulfated at $1050^{\circ} \mathrm{C}$. High magnification.

Figure 4.8 SEM photograph of sprayed CP sulfated at $1050^{\circ} \mathrm{C}$. Low magnification.

Figure 4.9 SEM photograph of sprayed CP sulfated at $1050^{\circ} \mathrm{C}$. High magnification.

Figure 4.10 Dual $\mathrm{SO}_{2}-\mathrm{NO}_{x}$ reduction by CMA as a function of temperature in atmospheres containing $3 \% \mathrm{O}_{2}, 2000 \mathrm{ppm} \mathrm{SO}$, and $1000 \mathrm{ppm} \mathrm{NO}$ in $\mathrm{N}_{2} . \mathrm{SO}_{2}$ reduction by wet and dry injection at $\mathrm{Ca} / \mathrm{S}=1$.

Figure 4.11 Dual $\mathrm{SO}_{2}-\mathrm{NO}_{x}$ reduction by CMA. $\mathrm{NO}_{x}$ reduction by wet and dry injection at $\mathrm{Ca} / \mathrm{S}=1$.

Figure 4.12 Dual $\mathrm{SO}_{2}-\mathrm{NO}_{x}$ reduction by $\mathrm{CMA}$. $\mathrm{SO}_{2}$ reduction by wet and dry injection at $\mathrm{Ca} / \mathrm{S}=2$.

Figure 4.13 Dual $\mathrm{SO}_{2}-\mathrm{NO}_{x}$ reduction by CMA. $\mathrm{NO}_{x}$ reduction by wet and dry injection at $\mathrm{Ca} / \mathrm{S}=2$. 
Figure 5.2 SEM of calcined CF sulfated at $1225 \mathrm{~K}$. Note formation of cylindrical protrusions.

Figure 5.3 SEM of calcined CF, cracked open to reveal interior voids and grainy shell structure.

Figure 5.4 SEM of unreacted calcium acetate. Note the brittle, elongated crystals of about $10 \mu \mathrm{m}$ in length and a few $\mu \mathrm{m}$ in width.

Figure 5.5 SEM of calcined CA sulfated at $1175 \mathrm{~K}$. The unreacted crystals have coalesced into spheres.

130

Figure 5.6 SEM of calcined CA, cracked open to reveal interior void and thin porous shell.

Figure 5.7 SEM of unreacted calcium propionate.

132

Figure 5.8 SEM of calcined CP sulfated at $1025 \mathrm{~K}$.

133

Figure 5.9 SEM of calcined CA, cracked open to reveal interior voids and grainy shell structure.

134

Figure 5.10 SEM of glassy cenosphere, cracked open to reveal thin, comparatively non-porous thin shell.

Figure 5.11 SEM of unreacted calcium benzoate. Note brittle, elongated crystals of $10 \mu \mathrm{m}$ in width and $30-50 \mu \mathrm{m}$ in length.

136

Figure 5.12 SEM of CB after calcination in air at $1275 \mathrm{~K}$. Note large blowholes on surface.

137

Figure 5.13 Calcined CB cracked open to reveal cenospheric structure and shell porosity. 138

Figure 5.14 Experimental apparatus. 140 
Figure 5.15 TGA profiles for CF, CA, CP and calcium carbonate. Rate of mass loss is in $\mathrm{mg} / \mathrm{s}$.

Figure 5.16 TGA profiles for CB. Rate of mass loss is in $\mathrm{mg} / \mathrm{s}$.

Figure 5.17 Pore volume distribution of sorbents calcined at gas temperatures between $750-950^{\circ} \mathrm{C}$ in $3 \% \mathrm{O}_{2}$. - CF; - - CA; -... CF.

Figure 5.18 Pore surface-area distribution of sorbents calcined at gas temperatures between $750-950^{\circ} \mathrm{C}$ in $3 \% \mathrm{O}_{2} .-\mathrm{CF} ;-.-\mathrm{CA} ; \ldots . \mathrm{CF}$. The differently-scaled inset shows the predominance of small pores in CA.

Figure 5.19 Removal of $\mathrm{SO}_{2}$ as a function of temperature in atmospheres containing $2000 \mathrm{ppm} \mathrm{SO}_{2}, 1000 \mathrm{ppm} \mathrm{NO}, 3 \% \mathrm{O}_{2}$ in $\mathrm{N}_{2}$ with containing $2000 \mathrm{ppm} \mathrm{SO} 2,1000 \mathrm{ppm} \mathrm{NO}, 3 \% \mathrm{O}_{2}$ in $\mathrm{N}_{2}$ with $\mathrm{Ca} / \mathrm{S}=3.1$. a) $\mathrm{SO}_{2}$ reduction. o without after-fire air; * with after-fire air; $\otimes, \circ 12 \% \mathrm{CO}_{2}$ added. b) $\mathrm{NO}_{x}$ reduction. $\mathrm{x}$ without after-fire air; + with after-fire air; $\oplus, \otimes 12 \% \mathrm{CO}_{2}$ added.

Figure 5.20 Removal of $\mathrm{SO}_{2}$ as a function of temperature in atmospheres containing $2000 \mathrm{ppm} \mathrm{SO}, 1000 \mathrm{ppm} \mathrm{NO}$, and $3 \% \mathrm{O}_{2}$ in $\mathrm{N}_{2}$ with $\mathrm{Ca} / \mathrm{S}$ molar ratios ranging between 2.4 and 3.1. o $\mathrm{CF} ; \mathrm{x} \mathrm{CA} ; * \mathrm{CP} ; \oplus \mathrm{CB} .150$

Figure 5.21 Reduction of $\mathrm{NO}_{x}$ as a function of temperature in atmospheres containing $2000 \mathrm{ppm} \mathrm{SO}, 1000 \mathrm{ppm} \mathrm{NO}$, and $3 \% \mathrm{O}_{2}$ in $\mathrm{N}_{2}$ with $\mathrm{Ca} / \mathrm{S}$ molar ratios ranging between 2.4 and 3.1. $\circ \mathrm{CF} ; \mathrm{x} \mathrm{CA} ; * \mathrm{CP} ; \oplus \mathrm{CB} .151$

Figure 5.22 $\mathrm{SO}_{2}$ reduction as a function of bulk $\phi$, including changes in $\mathrm{SO}_{2}$ reduction due to the addition of afterfire air. $\circ \mathrm{CF} ; \mathrm{x} \mathrm{CA} ; * \mathrm{CP} ; \oplus \mathrm{CB}$. $-950^{\circ} \mathrm{C} ;--750^{\circ} \mathrm{C}$. 
Figure 5.23 $\mathrm{NO}_{x}$ reduction as a function of bulk $\phi$, including changes in $\mathrm{NO}_{x}$ reduction due to the addition of afterfire air. o $\mathrm{CF} ; \mathrm{x} \mathrm{CA} ; * \mathrm{CP}$; $\oplus \mathrm{CB}$.

Figure 5.24 Calcium utilization as a function of temperature in atmospheres containing $2000 \mathrm{ppm} \mathrm{SO}, 1000 \mathrm{ppm} \mathrm{NO}$, and $3 \% \mathrm{O}_{2}$ in $\mathrm{N}_{2}$ with $\mathrm{Ca} / \mathrm{S}$ molar ratios ranging between 2.4 and 3.1. ० CF; $\mathrm{x} \mathrm{CA} ; * \mathrm{CP} ; \oplus \mathrm{CB} .158$

Figure 5.25 Changes in $\mathrm{Ca}$ utilization as a function of temperature due to the addition of afterfire air. o $\mathrm{CF} ; \mathrm{x} \mathrm{CA} ; * \mathrm{CP} ; \oplus \mathrm{CB}$.

Figure 5.26 $\mathrm{Ca}$ utilization as a function of bulk $\phi$, including changes in utilization due to the addition of afterfire air. o CF; $\mathrm{x} C \mathrm{CA} ; * \mathrm{CP} ; \oplus \mathrm{CB}$. $-950^{\circ} \mathrm{C} ;--750^{\circ} \mathrm{C}$.

Figure 5.27 The Pore Tree 163

Figure 5.28 Ca utilization vs. temperature, comparison of model calculation and experimental measurements. o data; - - model using $\mathrm{CaCO}_{3}$; model using $\mathrm{CaO} ; \cdot \cdot-\cdot$ model fit to data.

Figure 5.29 Percentage of $\mathrm{Ca}$ retained as $\mathrm{CaCO}_{3}$ in calcined sorbents. o $\mathrm{CF}$; $x \mathrm{CA} ; * \mathrm{CP} ;+$ pure $\mathrm{CaCO}_{3}(\mathrm{CC})$.

Figure 5.30 Sulfation kinetics of different sorbents. o CF; $\mathrm{x} C A ; * \mathrm{CP} ;-$ $\mathrm{CaCO}_{3} ;-\cdots \mathrm{CaO}$. Pre-exponential factors and activation energies are listed in Table IV.

Figure 6.1 Photograph of the experimental apparatus

Figure 6.2 Ca Utilization by $\mathrm{CF}$ and sucrose as a function of $\phi$ at $1000^{\circ} \mathrm{C}$ 
Figure 6.3 $\mathrm{NO}_{x}$ Reduction by $\mathrm{CF}$ and sucrose as a function of $\phi$ at $1000^{\circ} \mathrm{C}$

Figure I.1 SEM micrograph of plain pulverized coal.

Figure I.2 SEM micrograph of pulverized coal treated with CMA.

Figure I.3 Schematic of the furnace with the axial gas temperature profile and trajectory of burning particles

219

Figure I.4 SEM micrograph of plain pulverized coal after pyrolysis in nitrogen at $\mathrm{T}_{g}=1450 \mathrm{~K}$. Low magnification.

Figure I.5 SEM micrograph of plain pulverized coal after pyrolysis in nitrogen at $T_{g}=1450 \mathrm{~K}$. High magnification.

224

Figure I.6 SEM micrograph of CMA-treated pulverized coal after pyrolysis in nitrogen at $\mathrm{T}_{g}=1450 \mathrm{~K}$. Low magnification.

225

Figure I.7 SEM micrograph of CMA-treated pulverized coal after pyrolysis in nitrogen at $\mathrm{T}_{g}=1450 \mathrm{~K}$. High magnification.

226

Figure I.8 Three-color pyrometry intensity signals (top row) and two-color ratio temperature profiles (bottom row) for burning pulverized plain coal particles $(75-90 \mu \mathrm{m})$ in air at $T_{g}$ of $1450 \mathrm{~K}$. High-speed cinematography frames of some burning pulverized coal particles in air at $\mathrm{T}_{g}$ of $1450 \mathrm{~K}$ are included.

228

Figure I.9 Three-color pyrometry intensity signals (top row) and two-color ratio temperature profiles (bottom row) for burning aggregates of micronized coal particles in air at $T_{g}$ of $1450 \mathrm{~K}$. Frames from the high-speed cinematography are attached next to the traces

231 
Figure 1.10 Three-color pyrometry intensity signals (top row) and two-color ratio temperature profiles (bottom row) for burning pulverized CMAtreated coal particles $(75-90 \mu \mathrm{m})$ in air at $T_{g}$ of $1450 \mathrm{~K}$

Figure I.11 Three-color pyrometry intensity signals (top row) and two-color ratio temperature profiles (bottom row) for burning pulverized CA- and MA-treated coal particles $(75-90 \mu \mathrm{m})$ in air at $T_{g}$ of $1450 \mathrm{~K}$

Figure I.12 $\mathrm{SO}_{2}$ (-) and $\mathrm{NO}_{x}(--)$ emissions from pulverized (PSOC 1451, $75-90 \mu \mathrm{m}$ ) coal with and without sorbent treatment burning at $1450 \mathrm{~K}$. (i) plain; treated with (ii) CMA, (iii) CA, (iv) MA.

Figure I.13 $\mathrm{SO}_{2}(-)$ and $\mathrm{NO}_{x}(--)$ emissions from micronized (Otisca, $4 \mu \mathrm{m}$ ) coal with and without sorbent treatment burning at $1450 \mathrm{~K}$. (i) plain; treated with CMA burning in (ii) air, (iii) $40 \% \mathrm{O}_{2}$.

Figure I.14 $\mathrm{SO}_{2}(-)$ and $\mathrm{NO}_{x}(--)$ emissions from pulverized (PSOC 1451, $75-90 \mu \mathrm{m}$ ) coal with and without sorbent treatment burning at $1450 \mathrm{~K}$. (i) plain, sample extracted at the end of the isothermal zone; (ii) with CMA, sample extracted at the end of the isothermal zone; (iii) plain, sample extracted at the mid-height of the isothermal zone; (iv) with CMA, sample extracted at the mid-height of the isothermal zone. 239 
CHAPTER 1. 


\section{Overall Introduction}

\section{Problem Statement}

Emissions of $\mathrm{SO}_{2}$ and $\mathrm{NO}_{x}\left(\mathrm{NO}+\mathrm{NO}_{2}\right)$ from stationary combustion sources contribute to acid rain formation in the atmosphere; $\mathrm{NO}_{x}$ also contributes to the formation of urban smog and to the depletion of stratospheric ozone. Over half of the electricity generated in the USA is produced from the combustion of coals in plants that are major producers of $\mathrm{SO}_{2}$ and $\mathrm{NO}_{x}$. Vast reserves of coal are found in the USA and developing nations such as China and, indeed, coal is the most abundant fossil fuel in the world. It is expected that coal will continue to be used for fuel for a substantial length of time and that concerns relative to effective control of $\mathrm{SO}_{2}$ and $\mathrm{NO}_{x}$ will continue well into the future.

At present, the control of sulfur and nitrogen oxide emissions from coalfired power plants is achieved with separate processes often in multiple stages.

\subsection{Methods of Sulfur Reduction.}

Methods of reducing sulfur emissions can be placed in four general categories: 1) fuel substitution; 2) fuel desulfurization; 3) combustion process modification; and 4) desulfurization of combustion products.

1) Fuel Substitution. The sulfur content of different types of coals varies between 0.5 to $4 \%$. Substituting a low-sulfur coal for a high-sulfur coal will reduce sulfur emissions accordingly.

2) Fuel Desulfurization. Coal can be physically cleaned. Efforts to remove ash-forming compounds by physically crushing coal and then separating mineral impurities from the organic coal also remove some of the sulfur. Sulfur bounds organically to the coal substrate and inorganically with iron particles 
(pyrite) and it is the pyritic sulfur that is removed. Typically, $40 \%$ reduction in sulfur can be achieved by mechanical cleaning.(EPA, 1981).

3) Combustion Process Modification. Compounds containing $\mathrm{Ca}$ and $\mathrm{Mg}$ - most often limestone or dolomite - can be added to coal during combustion to react with fuel sulfur as it is released. For example, limestone can be added to coal burning in a fluidized bed, where the temperature is high enough to calcine the stone $\left(800-900^{\circ} \mathrm{C}\right)$ and create a more porous solid, but low enough to preclude both the dissociation of the resulting sulfate and/or sintering of the calcined stone. First, limestone calcinates:

$\mathrm{CaCO}_{3} \longrightarrow \mathrm{CaO}+\mathrm{CO}_{2}$

$\mathrm{SO}_{2}$ then reacts heterogeneously with the calcined stone. In an oxygen-rich atmosphere:

$\mathrm{CaO}+\mathrm{SO}_{2}+\frac{1}{2} \mathrm{O}_{2} \longrightarrow \mathrm{CaSO}_{4}$

In an oxygen-lean atmosphere:

$\mathrm{CaO}+\mathrm{H}_{2} \mathrm{~S} \longrightarrow \mathrm{CaS}+\mathrm{H}_{2} \mathrm{O}$

If the temperature is below the decomposition temperature of the carbonate, $\mathrm{SO}_{2}$ can also react directly with $\mathrm{CaCO}_{3}$ :

$\mathrm{CaCO}_{3}+\mathrm{SO}_{2}+\frac{1}{2} \longrightarrow \mathrm{CaSO}_{4}+\mathrm{CO}_{2}$

Calcium-based sorbents also have been added to coal by ion-exchange (Freund and Lyon, 1982) and by wetting pulverized and micronized coals with aqueous solutions of calcium magnesium acetate, calcium acetate and magnesium acetate (Atal, et al., 1994; Appendix 1).

4) Desulfurization of Combustion Products. Electric utilities in the USA rely on flue gas desulfurization (FGD) to control $\mathrm{SO}_{2}$ emissions for their newer facilities. FGD processes are either wet or dry (referring to the state of FGD products removed for disposal or regeneration) and wet systems dominate in the USA (EPA, 1981) and Japan (Ando, 1985) as well as Europe. FGD process are also either regenerative (sulfur is separated from the spent 
sorbent which can then be reused) or throwaway (the sulfur-sorbent product is discarded).

For example, the most widely used flue gas desulfurization strategies involve wet or dry scrubbing with non-regenerated calcium compounds such as slaked lime or limestone slurries. Injection of these sorbents in the hightemperature boiler gases also has received much attention because of the projected low capital investment. As an example of in-boiler sorbent injection, Cole, et al. (1986) reported that hydrated materials (e.g., slaked lime) were more reactive than limestone, and that dolomitic sorbents were more reactive than calcitic sorbents. They attributed the differences in reactivities to the higher surface area of hydrated sorbents compared to carbonic sorbents, and to the higher surface area of dolomitic sorbents compared with calcitic sorbents. For example, a mean surface area of $\approx 50 \mathrm{~m}^{2} / \mathrm{g}$ was measured for hydrated dolomitic sorbents compared with an average of $\approx 25 \mathrm{~m}^{2} / \mathrm{g}$ for hydrated calcitic sorbents. This resulted in average $\mathrm{Ca}$ utilizations of $\approx 26 \%$ and $\approx 16 \%$, respectively, for hydrated dolomitic and calcitic sorbents exposed to $2000 \mathrm{ppm} \mathrm{S \textrm {S } _ { 2 }}$ at $\approx 1100^{\circ} \mathrm{C}$ for 0.5 sec. with a $\mathrm{Ca} / \mathrm{S}$ molar ratio of 2 (Cole, et al., 1986). The correlation of $\mathrm{SO}_{2}$ reduction with sorbent surface area was also reported by Greene, et al. (1985) and the high surface area of dolomite was given as a reason for its high sulfur affinity. Evidence of pore structure was also reported to influence sulfation rates, with the plate-like pores of $\mathrm{CaO}$ from hydrated sorbents posing less diffusional resistance when compared to the sphere-shaped pores of $\mathrm{CaO}$ from calcitic sorbents (Bruce, et al., 1989).

Processes using magnesium are examples of regenerative FGD methods. At temperatures between 40 to $65^{\circ} \mathrm{C}$, magnesium hydroxide slurries react with $\mathrm{SO}_{2}$ to form hydrated magnesium sulfites $\left(\mathrm{MgSO}_{3} \bullet 3 \mathrm{H}_{2} \mathrm{O}\right.$ or $\left.\mathrm{MgSO}_{3} \bullet 6 \mathrm{H}_{2} \mathrm{O}\right)$. The sulfites are dried and calcined to recover $\mathrm{MgO}$ and $\mathrm{SO}_{2}$ for production of sulfuric acid or elemental sulfur (EPA, 1981; Flagan and Seinfeld, 1988). 
The low-temperature reactions between $\mathrm{Mg}$ and $\mathrm{S}$ compounds may be an additional reason why why utilities report improved $\mathrm{SO}_{2}$ removal when $\mathrm{MgO}$ is added to lime slurries (EPA, 1981).

\subsection{Methods of $\mathrm{NO}_{x}$ Reduction.}

For utility boilers in the USA, $50 \%$ of the $\mathrm{NO}_{x}$ emissions are attributed to coal combustion (EPA, 1983). Current $\mathrm{NO}_{x}$ reduction strategies fall into one of two categories: either 1) suppression of $\mathrm{NO}_{x}$ formation during combustion; or 2) removal of $\mathrm{NO}_{x}$ from the stack. Fuel substitution is not as practical as it is for $\mathrm{SO}_{2}$ reduction because $\mathrm{NO}_{x}$ can also be generated from atmospheric nitrogen. Moreover, the nitrogen content of coals is fairly consistently $\approx 1.5$ wt. \%, thus, it is not possible to substitute a low-nitrogen coal.

1) Suppression of $\mathrm{NO}_{x}$ Formation. To understand how altering operating conditions of a furnace controls $\mathrm{NO}_{x}$, it is necessary to understand how $\mathrm{NO}_{x}$ is formed during combustion. In coal combustion, $\mathrm{NO}$ emissions dominate $\mathrm{NO}_{x}$ emissions and $\mathrm{NO}$ readily oxidizes to $\mathrm{NO}_{2}$ at ambient conditions outside the stack.

Atmospheric nitrogen can form NO during combustion by two mechanisms: thermal fixation at high temperatures near stoichiometric combustion ("thermal-NO")(Zeldovich et al., 1947, in Flagan and Seinfeld, 1988; Hanson and Saliman, 1984); and low-temperature, fuel-rich, short residence-time formation ("prompt-NO")(Fenimore, 1971, in Flagan and Seinfeld, 1988; Bowman, 1975). Organically bound heterocyclic nitrogen compounds in coal also oxidize to NO during combustion ("fuel-NO") (Sarofim and Flagan, 1976) and create most of the $\mathrm{NO}_{x}$ emissions from coal (Beér, 1988).

Thermal-NO formation is sensitive to temperature and this characteristic is exploited in control strategies. Reducing the temperature to slow the rate of $\mathrm{N}_{2}$ oxidation can be achieved by low excess air firing, flue gas recirculation, 
and staging combustion so that a cooler, slower-burning, fuel-rich flame is followed by overfire air (Figure 1). Since the oxidation of fuel nitrogen is more sensitive to stoichiometry than temperature, staged combustion (a fuel-rich zone is followed by a fuel-lean zone) also controls fuel-NO. Low-NO $\mathrm{N}_{x}$ burners reduce the mixing rate between coal and air, providing the time required for $\mathrm{N}_{2}$ formation. The most popular $\mathrm{NO}_{x}$ control methods for USA coal-fired utility boilers are staged combustion or low- $\mathrm{NO}_{x}$ burners (EPA, 1983).

However, present combustion modifications may be approaching the limit of their $\mathrm{NO}_{x}$ reduction capabilities and these techniques alone are insufficient, at times, to meet the regulations for $\mathrm{NO}_{x}$ emissions from coal-fired boilers. For example, combustion modifications from tangential and wall-fired boilers have resulted in $\mathrm{NO}_{x}$ emissions of $220-440 \mathrm{ppm}$ (at $3 \%$ oxygen) whereas $\mathrm{NO}_{x}$ emission regulations for coal-fired boilers are between $\approx 100-360 \mathrm{ppm}$ at $6 \%$ $\mathrm{O}_{2}$ or 80 to $300 \mathrm{ppm}$ at $3 \% \mathrm{O}_{2}$ (Bowman, 1992). Hence, to remove a sufficient amount of $\mathrm{NO}_{x}$, it will be necessary to use some post-combustion treatment.

2) Post-Combustion Removal of $\mathrm{NO}_{x}$. The major post-combustion $\mathrm{NO}_{x}$ emissions destruction methods are 1) selective non-catalytic reduction (SNCR) and selective catalytic reduction (SCR) wherein nitrogen-containing compounds (e.g., ammonia (Lyon, 1974) and urea (Arand, et al., 1982)) are injected downstream of the boiler; and 2) injection of secondary fuels in a fuel-rich zone downstream of the primary combustion zone (Myerson, 1975; Figure 2).

$\mathrm{NO}_{x}$ reductions of $80-90 \%$ have been reported for SNCR and SCR at a $\mathrm{RN} / \mathrm{NO}$ molar ratio of 2. However, $\mathrm{N}_{2} \mathrm{O}$ and $\mathrm{SO}_{3}$ (if $\mathrm{SO}_{2}$ is present) may be released depending on the type of catalyst used in $\mathrm{SCR}$. $\mathrm{NH}_{3}$ may be released depending on the amount of ammonia slip in SNCR (Bowman, 1992).

When a secondary fuel such as methane is injected to create a fuel-rich zone, $\mathrm{CH}_{i}$ radicals react with $\mathrm{NO}$ to reduce it to $\mathrm{N}_{2}$. The reaction paths include 


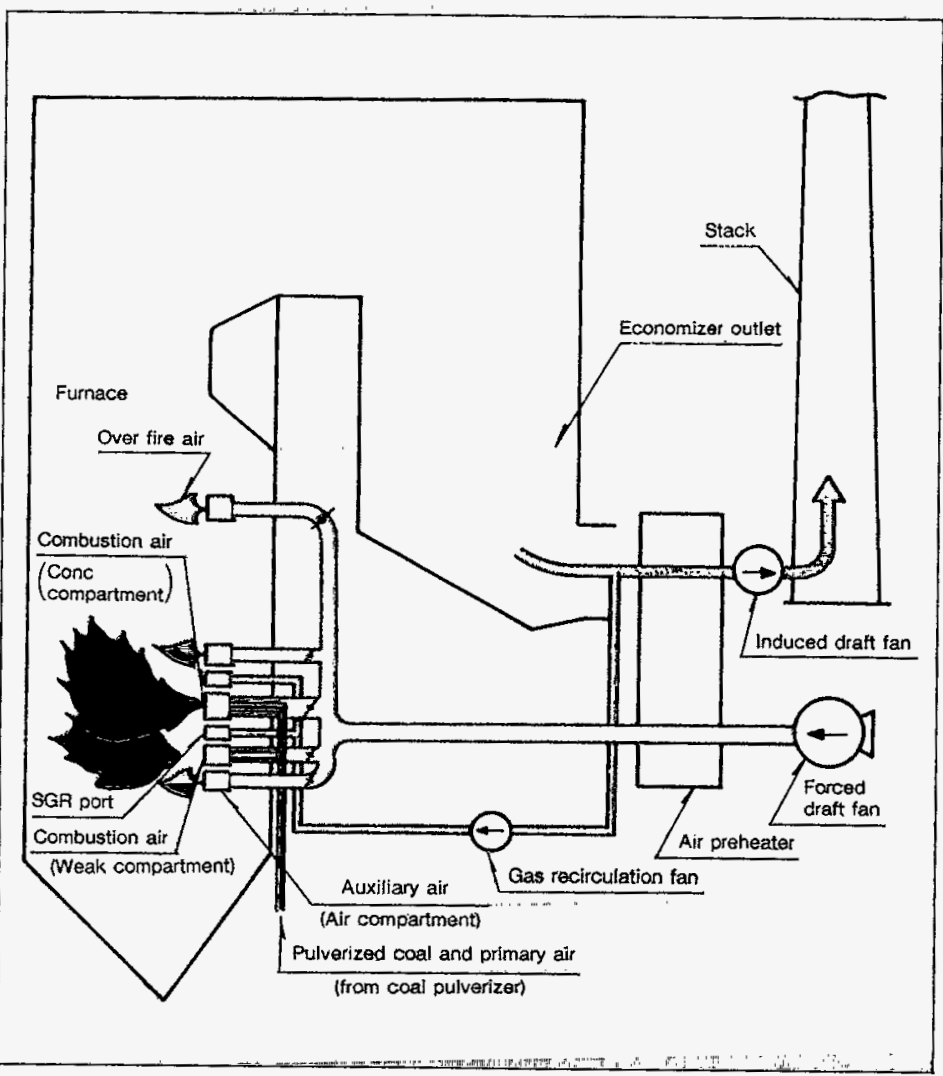

Figure 1: A schematic of staged combustion for $\mathrm{NO}_{x}$ control in a pulverizedcoal boiler. Courtesy of Mitsubishi Heavy Industries, LTD. 


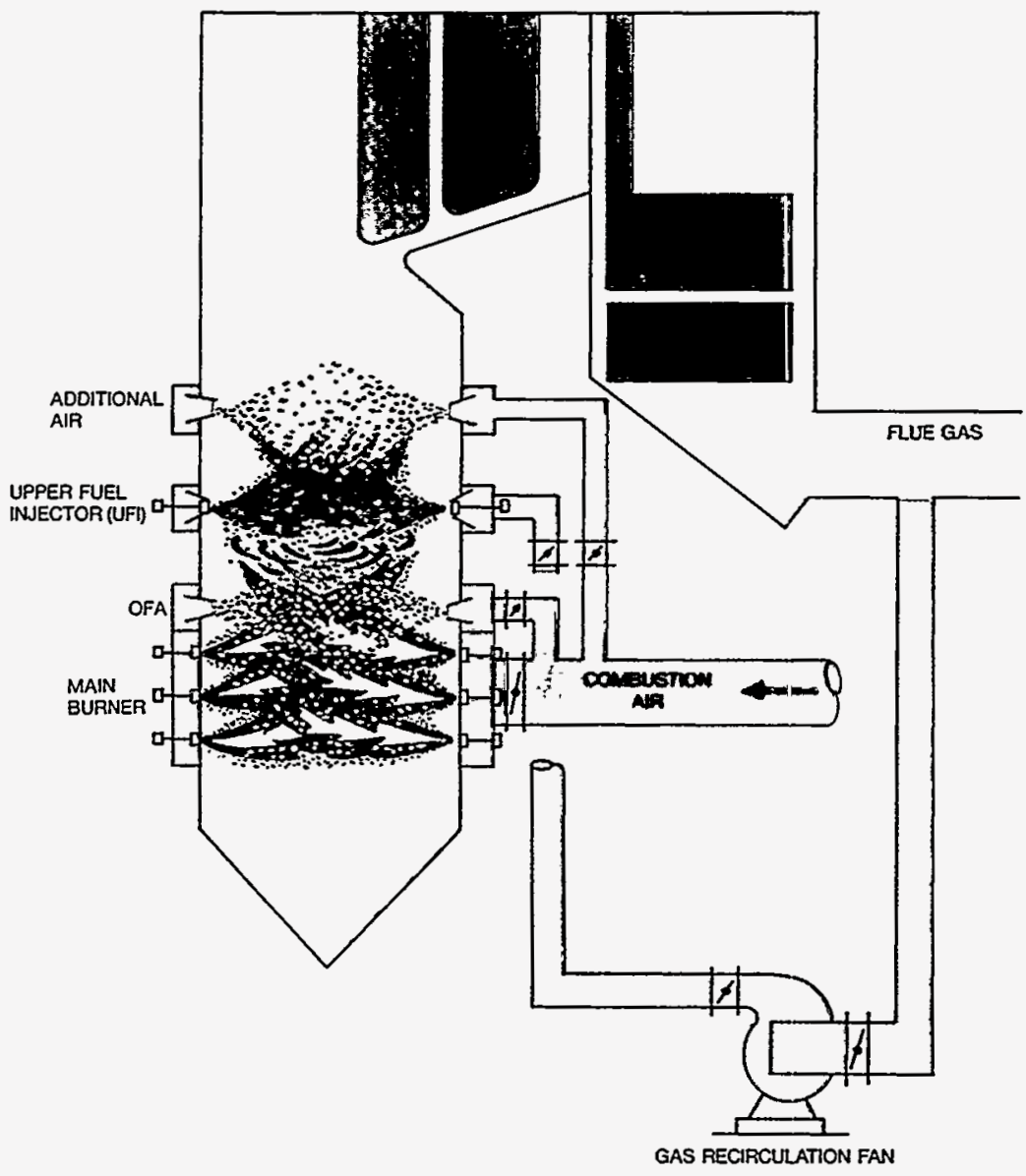

Figure 2: A schematic of post-combustion secondary fuel injection for $\mathrm{NO}_{x}$ control in a coal-fired boiler. Courtesy of Mitsubishi Heavy Industries, LTD. 
the formation of $\mathrm{CH}$ and $\mathrm{NH}$ compounds and are similar to those followed in prompt-NO and fuel-NO (Beér, 1988; Miller and Bowman, 1989). Injection of air after the fuel-rich zone completes the oxidation of $\mathrm{CO}$, unburned hydrocarbons, and any small amount of $\mathrm{HCN}$ or $\mathrm{NH}_{3}$ (Myerson, 1975). In coal-fired furnaces, $\mathrm{NO}_{x}$ reduction efficiencies of $70 \%$ for cyclone-fired boilers (Yagiela, et al., 1991) and $40-50 \%$ for wall-fired and tangentially-fired boilers (Bowman, 1992) have been reported when natural gas was used as the secondary fuel. $\mathrm{NO}_{x}$ reductions of $60 \%$ were reported for a pilot-scale furnace using pulverized coal as the secondary fuel (Bowman, 1992).

\subsection{Dual $\mathrm{SO}_{2}-\mathrm{NO}_{x}$ Control.}

If control of both pollutants is desired, the current strategy is simply to combine separate $\mathrm{SO}_{2}$ and $\mathrm{NO}_{x}$ removal processes, e.g., low- $\mathrm{NO}_{x}$ burners are combined with wet or dry desulfurization by using throwaway calcium compounds such as slaked lime or limestone slurries. Few processes exist where one control agent is used for the simultaneous removal of $\mathrm{SO}_{2}$ and $\mathrm{NO}_{x}$.

This research is a study of the control of $\mathrm{SO}_{2}$ and $\mathrm{NO}_{x}$ emissions from coal combustion by post-combustion injection of carboxylic salts. The process could be classified as the injection of a secondary fuel to control $\mathrm{NO}_{x}$ occurring simultaneously with the wet or dry injection of a non-regenerative $\mathrm{SO}_{2}$ sorbent. The study is based on laboratory-scale experiments in a high temperature furnace. The furnace simulates the post-combustion environment in coal-fired boilers by achieving similar temperatures and concentrations of $\mathrm{SO}_{2}, \mathrm{NO}$, and $\mathrm{O}_{2}$. While most of the nitrogen oxide emission from coal combustion is in the form of $\mathrm{NO}$, some $\mathrm{NO}$ may oxidize to $\mathrm{NO}_{2}$ in the furnace, hence, the total reduction of both oxides, $\mathrm{NO}_{x}$, was actually measured in the experiments. The emphasis of this research was on developing an understanding of the mechanisms of $\mathrm{SO}_{2}$ and $\mathrm{NO}_{x}$ removal, optimizing the temperature and rate of 
sorbent injection that achieved the most efficient reduction, and investigating the presence of additional pollutants, such as $\mathrm{CO}, \mathrm{H}_{2} \mathrm{~S}, \mathrm{HCN}, \mathrm{NH}_{3}$ and $\mathrm{N}_{2} \mathrm{O}$, that may be created from reactions between the salts, $\mathrm{SO}_{2}$ and $\mathrm{NO}$.

Why are carboxylic calcium and magnesium salts candidate agents for the simultaneous removal of the pollutants $\mathrm{SO}_{2}$ and $\mathrm{NO}_{x}$ from the effluent of coalfired stationary boilers? The unique chemical structure of the salts - a combination of alkaline earth metals and organic hydrocarbons - is the key to their efficacy as dual $\mathrm{SO}_{2}-\mathrm{NO}_{x}$ reducing agents. When the salts are injected into a hot environment containing $\mathrm{SO}_{2}$ and $\mathrm{NO}_{x}$ (e.g., in a boiler just downstream of the primary combustion burner), they calcine, releasing hydrocarbon radicals and leaving behind porous cenospheres of $\mathrm{CaCO}_{3}, \mathrm{CaO}$ or $\mathrm{MgO}$. The carbonate and oxides react with $\mathrm{SO}_{2}$ to form $\mathrm{CaSO}_{4}$ and $\mathrm{MgSO}_{4}$. In the oxygen-lean atmosphere, the hydrocarbon radicals react with $\mathrm{NO}$ to form $\mathrm{N}_{2}$. In addition, $\mathrm{CaO}$ can act as a catalyst during the reduction of NO.

\section{Outline of Present Work}

The unique capability of CMA and other carboxylic salts to serve as dual $\mathrm{SO}_{2}$ and $\mathrm{NO}_{x}$ reducing agents has not been explored by other investigators. Previous work in oxidizing atmospheres (Levendis, et al., 1993) identified the encouraging $\mathrm{SO}_{2}$ sorption characteristics of CMA and $\mathrm{CA}$ compared to traditional $\mathrm{SO}_{2}$ sorbents including calcium hydroxide (slaked lime) and calcium carbonate (limestone). The next step was to determine the efficiency of the carboxylic salts as $\mathrm{NO}_{x}$ reduction agents by injecting them into reducing atmospheres containing NO (Chapter 2).

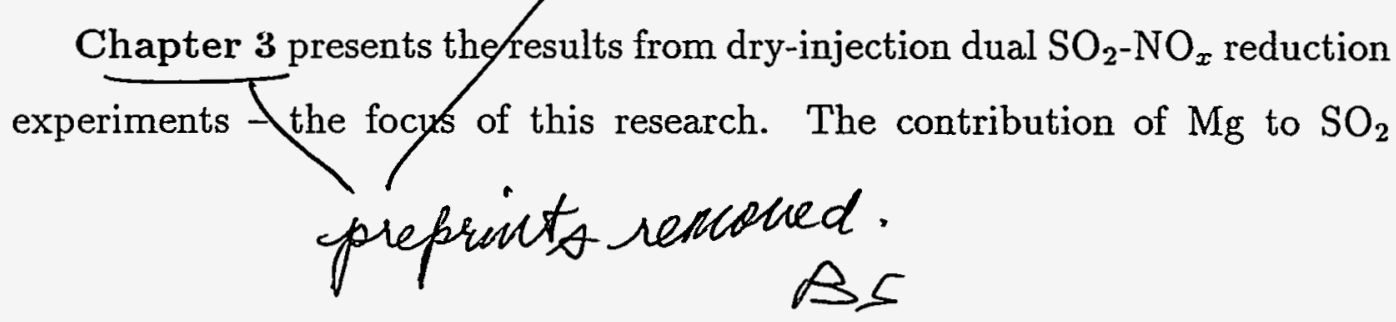


reduction was quantified. Other aspects of the dual $\mathrm{SO}_{2}-\mathrm{NO}_{x}$ reduction process are addressed in subsequent chapters.

The high solubility of the salts permits their injection as solutions. Fine mists - and subsequently small aerosols of $\mathrm{CaO}$ and $\mathrm{MgO}$ - are thus obtained and promote more efficient heterogeneous reaction between gaseous $\mathrm{SO}_{2}$ and the solid oxides (Chapter 4). coyf cycled sypuately

The importance of the organic hydrocarbons on $\mathrm{SO}_{2}-\mathrm{NO}_{x}$ reduction was explored in Chapter 5 by simultaneous $\mathrm{SO}_{2}-\mathrm{NO}_{x}$ reduction experiments using carboxylic calcium salts with different amounts of aliphatic hydrocarbons (formate, acetate and propionate). The importance of organic structure was explored using a calcium salt with an aromatic hydrocarbon (calcium benzoate). Calcium utilizations obtained experimentally were compared to utilizations calculated with a cenospheric sulfation model.

Commercial sources of carboxylic salts are expensive due to the manufacture of the acid (formic, acetic, or propionic) from natural gas. Alternatives to reduce cost include manufacture of the acids from biomass, sewage sludge, or even - in the case of benzoic acid - from coal, and improving the utilization of the alkali earth metals while combining them with other sources of less expensive hydrocarbon fuels, including lignite. Chapter 6 presents some of these carboxylic salt combinations, enhancers and "analogs" that may provide a cost-effective solution to simplify $\mathrm{SO}_{2}$ and $\mathrm{NO}_{x}$ removal from existing power plants. This chapter also presents calculations to illustrate the economics of different $\mathrm{SO}_{2}-\mathrm{NO}_{x}$ reduction schemes.

Chapter 7 summarizes the most important findings of this investigation and presents recommendations for future research.

While the main purpose of this work was the study of post-combustion injection of sorbents for removal of $\mathrm{SO}_{2}$ and $\mathrm{NO}_{x}$, Appqndix 1 describes experiments in conjunction with a separate project that were performed to

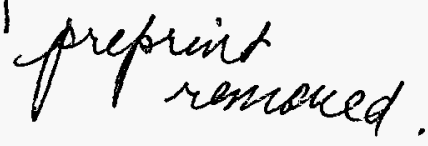


assess the efficacy of pre-treating coal with carboxylic acid salts. In these experiments, coal particles of different size and sulfur content were treated with CMA, CA and MA. Treated and untreated particles were burned in air at the temperatures expected in pulverized coal burners. Virtually no $\mathrm{SO}_{2}$ was detected during the combustion of treated pulverized coal particles.

Appendices $\mathbf{2}$ and 3 contain example calculations of equivalence ratios, chemical thermodynamics and chemical kinetics.

\section{References}

- -, "Control Techniques for Sulfur Oxide Emissions from Stationary Sources - Second Edition," EPA-450/3-81-004, U. S. Environmental Protection Agency, Research Triangle Park, NC, April, 1981.

- -, "Control Techniques for Nitrogen Oxides Emissions from Stationary Sources - Revised 2nd Edition," EPA-450/3-83-002, U. S. Environmental Protection Agency, Research Triangle Park, NC, January, 1983.

- Ando, J., "Recent Developments in $\mathrm{SO}_{2}$ and $\mathrm{NO}_{x}$ Abatement Technology for Stationary Sources in Japan," EPA/600/S7-85/040, U. S. Environmental Protection Agency, Research Triangle Park, NC, November, 1985.

- Arand, J. K., Muzio, L. J., and Teixeria, D. P., "Urea Reduction of $\mathrm{NO}_{x}$ in Fuel Rich Combustion Effluents," US Patent No. 4,325,924, 1982.

- Atal, A., Steciak, J., and Levendis, Y. A., "Combustion and $\mathrm{SO}_{2}-\mathrm{NO}_{x}$ Emissions of Bituminous Coal Particles Treated with CMA," accepted for publication in Fuel, 1994. 
- Beér, J., "Stationary Combustion: The Environmental Leitmotif," TwentySecond Symposium (International) on Combustion, The Combustion Institute, Pittsburgh, PA, pp. 1-16, 1988.

- Bowman, C. T., "Kinetics of Pollutant Formation and Destruction in Combustion," Progress in Energy and Combustion Science, 1, pp. 33$34,1975$.

- Bowman, C. T., "Control of Combustion-Generated Nitrogen Oxide Emissions: Technology Driven by Regulation," Twenty-Fourth Symposium (International) on Combustion, The Combustion Institute, Pittsburgh, PA, pp. 859-878, 1992.

- Bruce, K. R., Gullet, B. K., and Beach, L. O., "Comparative $\mathrm{SO}_{2}$ Reactivity of $\mathrm{CaO}$ Derived from $\mathrm{CaCO}_{3}$ and $\mathrm{Ca}(\mathrm{OH})_{2}, "$ AlChE Journal, 35(1), 37 (1989).

- Cole, J. A., Kramlich, J. C., Seeker, W. R., Silcox, G. D., Newton, G. H., Harrison, D. J., and Pershing, D. W., "Fundamental Studies of Sorbent Reactivity in Isothermal Reactors," Proceedings: 1986 Joint Symposium on Dry $\mathrm{SO}_{2}$ and Simultaneous $\mathrm{SO}_{2} / \mathrm{NO}_{x}$ Control Technologies, " EPRI CS-4966, December, 1986.

- Flagan, R. C., and Seinfeld, J. H., Fundamentals of Air Pollution Engineering, Prentice Hall, NJ, 1988.

- Freund, H., and Lyon, R. K., "The Sulfur Retention of Calcium-Containing Coal During Fuel-Rich Combustion," Combustion and Flame, 45, pp. 191-203, 1982.

- Greene, S. B., Chen, S. L., Clark, W. D., Heap, M. P., Pershing, D. W., and Seeker, W. R., "Bench-Scale Process Evaluation of Reburning 
and Sorbent Injection for Infurnace $\mathrm{NO}_{x} / \mathrm{SO}_{x}$ Reduction," Environmental Protection Agency, Research Triangle Park, NC, EPA/600/7-85/012, 1985.

- Hansen, R. K., and Saliman, S., "Survey of Rate Constants in the N-HO System," in Combustion Chemistry, W. C. Gardiner, Ed., SpringerVerlag, New York, pp. 361-421, 1984.

- Levendis, Y. A., Zhu, W., Wise, D. L., and Simons, G. A., "The Effectiveness of Calcium Magnesium Acetate (CMA) as an $\mathrm{SO}_{x}$ Sorbent in Coal Combustion," AIChE J., Vol. 39, No. 5, p. 761, 1993.

- Lyon, R. K., "Method for the Reduction of the Concentration of NO in Combustion Effluents Using Ammonia," US Patent No. 3,900,554, 1975.

- Myerson, A. L., "Method for Removing the Oxides of Nitrogen as Air Contaminants," US Patent No. 3,867,507, 1975.

- Miller, J. A., and Bowman, C. T., "Mechanism and Modeling of Nitrogen Chemistry in Combustion," Progress in Energy and Combustion Science, 15, 187, 1989.

- Sarofim, A. F., and Flagan, R. C., "NO${ }_{x}$ Control for Stationary Combustion Sources," Progress in Energy and Combustion Science," 2, pp. 1-25, 1976.

- Yagiela, A. S., Maringo, G. J., Newell, R. J., and Farzan, H., "Update on Coal Reburning Technology for Reducing $\mathrm{NO}_{x}$ in Cyclone Boilers," American Power Conference, Chicago, 1991. 
CHAPTER 6. 


\title{
Custom-Blended Secondary Fuel and Sorbent Injection for Dual $\mathrm{SO}_{2}-\mathrm{NO}_{x}$ Emission Control
}

\begin{abstract}
Estimations of operating costs suggested that the application of calcium and magnesium carboxylic acid salts for dual $\mathrm{SO}_{2}-\mathrm{NO}_{x}$ reduction is practical only if a) the cost of the carboxylic acid salts can be significantly reduced; b) the utilization of the alkali earth metals by $\mathrm{SO}_{2}$ is improved; and 3) part of the organic acid can be replaced by less expensive hydrocarbons for $\mathrm{NO}_{x}$ reduction. This study explored the latter requirement by investigating the dual reduction of $\mathrm{SO}_{2}-\mathrm{NO}_{x}$ by combinations of calcium carboxylic acid salts and auxiliary hydrocarbons. The addition of lignite to achieve fuel-rich conditions with calcium propionate injected at a $\mathrm{Ca} / \mathrm{S}$ molar ratio of $\approx 2$ improved $\mathrm{NO}_{x}$ reduction from $35 \%$ to $80 \%$. Including $\mathrm{MgO}$ in the above blend so that $(\mathrm{Ca}+\mathrm{Mg}) / \mathrm{S}=2$ improved $\mathrm{SO}_{2}$ capture from $15 \%$ to $30 \%$. Blends of calcium formate and sucrose, injected at $\mathrm{Ca} / \mathrm{S}=1$ or 2 with varying amounts of sucrose to vary $\phi$, showed increases in both $\mathrm{NO}_{x}$ and $\mathrm{SO}_{2}$ reduction as $\phi$ increased. Excellent $\mathrm{SO}_{2}-\mathrm{NO}_{x}$ reductions exceeding $90 \%$ were obtained by dry-injection of a blend consisting of calcium formate and poly(ethylene), warranting a more through investigation of replacing part of the expensive carboxylic acid by wastes that would otherwise be landfilled.
\end{abstract}




\section{Introduction and Literature Review}

Aliphatic carboxylic acid salts of $\mathrm{Ca}$ and $\mathrm{Mg}$, e.g., calcium magnesium acetate (CMA), calcium formate (CF) and calcium propionate (CP), are effective agents for the simultaneous removal of $\mathrm{SO}_{2}$ and $\mathrm{NO}_{x}$ emitted from the combustion of coal. Over $90 \%$ removal of these pollutants has been obtained by dry-injecting CMA in laboratory-scale experiments at temperatures near $1000^{\circ} \mathrm{C}$ in oxygen-lean atmospheres $\left(3 \% \mathrm{O}_{2}, 12 \% \mathrm{CO}_{2}, 2000 \mathrm{ppm} \mathrm{SO}_{2}\right.$ and $1000 \mathrm{ppm} \mathrm{NO}$ in $\mathrm{N}_{2}$ ) at a molar $\mathrm{Ca} / \mathrm{S}$ ratio of 2 for a nominal 1 second residence time. Common thermodynamic and chemical kinetics windows wherein the dual reaction mechanisms are effective are defined by temperature (950 $\left.1150^{\circ} \mathrm{C}\right)$, residence time $(1-4 \mathrm{~s})$, and bulk equivalence ratio $(\phi$ between 1.1 and 1.3). The fuel-rich reaction zone is followed by a fuel-lean after-fire air zone, wherein occurs the oxidation of a) $\mathrm{CO}$ to $\mathrm{CO}_{2}$; b) unburned $\mathrm{HCs}$ to $\mathrm{CO}_{2}$ and water; and c) $\mathrm{NH}_{3}$ to $\mathrm{NO}_{x}$; and the continued sulfation of $\mathrm{Ca}$ to $\mathrm{CaSO}_{4}$. Previous work exploring dual $\mathrm{SO}_{2}-\mathrm{NO}_{x}$ reduction quantified the contribution of $\mathrm{Mg}$ to $\mathrm{SO}_{2}$ reduction by CMA (Steciak, et al., 1994d), showed that substantial amounts of $\mathrm{CaCO}_{3}$ remain in the residues due to the incomplete decomposition of $\mathrm{CaCO}_{3}$ to $\mathrm{CaO}$ - leading to the direct sulfation of $\mathrm{CaCO}_{3}$, and that the sulfation kinetics of the residues were bounded between those of pure $\mathrm{CaO}$ and pure $\mathrm{CaCO}_{3}$ (Steciak, et al., 1994b, Steciak, et al., 1994d).

Commercially available carboxylic acid salts are expensive due to the cost of manufacturing the organic acid from natural gas. Research is underway at Northeastern University to develop manufacturing processes for extracting carboxylic acids from organic sources such as municipal waste, sewage sludge, and woody biomass. The simple calculations of operating costs that follow illustrate the economic challenge to improve the utilization of the alkali earth metals in the salts and reduce the cost of the organic components.

Consider a 1,000 MW plant burning coal with a thermal efficiency $\eta_{t h}$ 
of 0.45 . The thermal work input is thus $W_{t h}=\frac{1000}{0.45}=2,222 \mathrm{MW}$. For a bituminous coal with a heating value of approximately $\Delta H_{c}=30,000 \mathrm{~kJ} / \mathrm{kg}$, the amount of coal that must be burned every day is

$\dot{m}_{c}=W_{t h}(\mathrm{MW}) \frac{1}{\Delta H_{c}}\left(\frac{\mathrm{kg}}{\mathrm{kJ}}\right) \cdot 3600\left(\frac{\mathrm{sec}}{\mathrm{hr}}\right) \cdot 24\left(\frac{\mathrm{hr}}{\mathrm{day}}\right)=6,400$ metric tons of coal per day.

If we assume that the coal contains $1.5 \%$ sulfur, then the mass of sulfur generated each day is $\dot{m}_{s}=0.015 \cdot \dot{m}_{c}=96$ metric tons; further assume that all of this sulfur is oxidized to $\mathrm{SO}_{2}$, i.e. 192 metric tons of $\mathrm{SO}_{2}$ are emitted daily. For the control of $\mathrm{SO}_{2}$ emissions (with a $\mathrm{Ca}$ utilization of $15 \%$ (Greene, et al, 1985)), an $\mathrm{SO}_{2}$ sorbent must be injected at a $\mathrm{Ca} / \mathrm{S}$ molar ratio of 2 to achieve $30 \%$ reduction. Assume that limestone $\left(\mathrm{CaCO}_{3}\right)$ is used. Hence, the mass of $\mathrm{CaCO}_{3}$ that must be injected is $\dot{m}_{\mathrm{CaCO}_{3}}=\dot{m}_{s} \cdot \frac{\mathrm{Ca}}{\mathrm{S}} \cdot \frac{M W_{\mathrm{CaCO}_{3}}}{M W_{S}}=600$ metric tons or $\approx 9 \%$ of the mass of coal burned and, at $\$ 20$ per metric ton for limestone, $\$ 12,000$ per day is spent for $\mathrm{SO}_{2}$ removal. Assuming that $20 \%$ of the coal is actually natural gas (methane) or lignite used as reburning fuel to remove $\mathrm{NO}_{x}$, the daily cost of removing $\mathrm{NO}_{x}$ by reburning with natural gas is

$0.20 \cdot \dot{\mathrm{m}}_{\mathrm{c}}\left(\frac{\mathrm{m} \cdot \mathrm{ton}}{\mathrm{day}}\right) \cdot \frac{1000 \mathrm{~kg}}{\mathrm{~m} \cdot \mathrm{ton}} \cdot \frac{1}{16} \frac{\mathrm{mol}}{\mathrm{g}} \cdot \frac{1000 \mathrm{~g}}{\mathrm{~kg}} \cdot 75,000 \frac{\mathrm{J}}{\mathrm{mol}} \cdot \frac{\$ 2.5}{\mathrm{GJ}} \cdot \frac{\mathrm{GJ}}{10^{9} \mathrm{~J}}=\$ 15,000$ per day.

The daily cost of reburning with lignite to remove $\mathrm{NO}_{x}$ is

$$
0.20 \cdot \dot{m}_{c}\left(\frac{\mathrm{m} \cdot \operatorname{ton}}{\text { day }}\right) \cdot \frac{1000 \mathrm{~kg}}{\mathrm{~m} . \operatorname{ton}} \cdot 17,200 \frac{\mathrm{kJ}}{\mathrm{kg}} \cdot \frac{\$ 1.5}{\mathrm{GJ}} \cdot \frac{\mathrm{GJ}}{10^{6} \mathrm{~kJ}}=\$ 33,000 \text { per day. }
$$

Hence, the total daily cost of $\mathrm{SO}_{2}$ and $\mathrm{NO}_{x}$ removal is $\$ 27,000$ to $\$ 45,000$, depending on the type of fuel used for reburning (natural gas and lignite, respectively), requires $\approx 30 \%$ of the mass of fuel input to be injected, and only a third of the generated $\mathrm{SO}_{2}$ is removed. $\mathrm{NO}_{x}$ removal of $70 \%$ has been reported by Greene, et al. (1985) for reburning with propane and as high as $70 \%$ in cyclone- fired boilers using natural gas as the reburning fuel (Yagiela, et. al., 1991). 
Now consider the application of CMA for the simultaneous removal of $\mathrm{SO}_{2}$ and $\mathrm{NO}_{x}$ in the same power plant. At a $\mathrm{Ca} / \mathrm{S}$ molar ratio of 2 , the mass of CMA that must be injected is $\dot{m}_{\mathrm{CMA}}=\dot{m}_{s} \cdot \frac{\mathrm{Ca}}{\mathrm{S}} \cdot \frac{M W_{C M A}}{M W_{S}}=2,650$ metric tons per day, or $\approx 40 \%$ of the mass of coal burned (the MW of CMA is $442 \mathrm{~g} / \mathrm{mol}$; note that this quantity of CMA corresponds to $33 \%$ of the mass of input fuel being used for $\mathrm{NO}_{x}$ and $8 \%$ for $\mathrm{SO}_{2}$ removal). At a price of $\$ 600 /$ ton, this corresponds to $\$ 1.6$ million per day, or about 35 to 60 times more expensive than limestone and lignite or natural gas, respectively. A lighter carboxylic acid salt such as CP $(186 \mathrm{~g} / \mathrm{mol})$ would still cost $\$ 1.3$ million per day, or 28 to 60 times more expensive than limestone and lignite or natural gas, respectively. Clearly, even though nearly all the $\mathrm{SO}_{2}$ can be removed, the daily operational costs of using carboxylic acid salts must be reduced for practical application.

Boosting the utilization of the alkali earth metals in the carboxylic acid salts and reducing the cost of their organic component, either by manufacturing inexpensive carboxylic acids or by partial substitution of the organic by other traditional fuels such as natural gas or lignite, will reduce their cost. Assume a) a $\mathrm{Ca} / \mathrm{S}$ molar ratio of 0.667 (or $50 \%$ utilization per alkali earth element in the CMA molecule); b) an order-of-magnitude reduction in the cost due to advanced techniques for generation of carboxylic acids from organic wastes; and c) substitution of natural gas or lignite for the additional hydrocarbons needed to achieve fuel-rich conditions for reburning. Under this scheme, the daily cost of CMA and lignite or natural gas is about twice the cost of limestone and natural gas, and about $30 \%$ more expensive than limestone and lignite; about $22 \%$ of the mass of input fuel would be injected for $\mathrm{SO}_{2}$ and $\mathrm{NO}_{x}$ reduction.

Another interesting scheme would combine wet injection of a low molecular weight carboxylic acid (e.g., CF) with alternative fuels such as plastics in the municipal waste stream. The power plant would team $65 \%$ calcium utilization 
obtained with wet injection (Steciak, et al., 1994c) with hydrocarbons that the plant might be payed to dispose of. The economics of this approach still require a drastic reduction in the price of carboxylic acids. Assuming that the price of CF can be lowered to one-tenth of the current price of $\$ 600$ per ton for CMA, the combination of CF and "free" hydrocarbons would be a third more expensive than limestone and natural gas, but $20 \%$ less expensive than limestone and lignite.

Other factors need to be considered. For example, deriving carboxylic acids from organic wastes diverts mass from landfills and captures "greenhouse" gases from natural decomposition that would otherwise be released into the atmosphere. The direct use of plastics and cellulosic materials - which would need to be finely shredded or ground - would divert considerable material from landfills. The inadvertent presence of chlorinated hydrocarbons, e.g., poly(vinyl chloride), might be tolerable because of the affinity of $\mathrm{Ca}$ for $\mathrm{Cl}$ to form $\mathrm{CaCl}_{2}{ }^{1}$ in the fuel-lean after-fire air zone (Dougherty, et al., 1993).

For the above reasons, we were interested in combining carboxylic acid salts with different amounts and types of hydrocarbons (e.g., an oxygen-containing hydrocarbon (sucrose) and a traditional fuel (lignite)). In addition, a few experiments were performed with poly(ethylene), a polymer found in quantity in the municipal waste stream ${ }^{2}$. The advantage of the custom-blended sorbents is the ability to deliver to a particular exhaust system, with its characteristic $\mathrm{SO}_{2}$ and $\mathrm{NO}_{x}$ concentrations, a single injection of materials that have been optimized for the most efficient simultaneous removal of $\mathrm{SO}_{2}-\mathrm{NO}_{x}$.

Previous work by Greene, et al. (1985) combined the injection of secondary fuels (various pulverized coals and propane) for $\mathrm{NO}_{x}$ reduction with the injection of calcium-based sorbents for $\mathrm{SO}_{2}$ control. They concluded that the

\footnotetext{
${ }^{1} \mathrm{CaO}+2 \mathrm{H}-\mathrm{C}+\mathrm{C}-\mathrm{Cl}+4 \mathrm{O}_{2} \longrightarrow \mathrm{CaCl}_{2}+4 \mathrm{CO}_{2}+\mathrm{H}_{2} \mathrm{O}$
}

28 million tons of poly(ethylene) were discarded in 1990 (Wheatly and Levendis, 1993) 
optimum location for sorbent injection was with the after-fire air because of increased reactivity of the calcined stone at $1000-1100^{\circ} \mathrm{C}$ (gas temperature at the location of after-fire air injection) compared to stone reactivity at $1400^{\circ} \mathrm{C}$ (gas temperature at the secondary fuel injection location). In our approach, the dual $\mathrm{SO}_{2}-\mathrm{NO}_{x}$ reduction can occur at the same temperature which is several hundred degrees Centigrade lower than the usual in-boiler secondary-fuel injection temperature for $\mathrm{NO}_{x}$ reduction in a "reburning" scheme (Wendt, et al., (1973)). Hence, loss of stone reactivity due to sintering is avoided and the simplicity of a single injection point is maintained - provided that one uses a secondary fuel that decomposes easily at the lower injection temperature. Incomplete sorbent calcination at injection temperatures below $1100^{\circ} \mathrm{C}$ and the lower rate of $\mathrm{CaO}$ sulfation at these temperatures are not detrimental because of the direct sulfation of $\mathrm{CaCO}_{3}$ (Steciak, et al., 1994b, d; Tullin, et al., 1989; Snow, et al., 1988) and the sulfation of $\mathrm{Mg}$ if it is present in the stone.

\section{Experimental Apparatus}

The apparatus used was the same as that described in detail previously (Steciak, et al., 1994a-d, etc). Basically, the high-temperature bench-scale furnace consisted of an isothermal high temperature zone followed by a quenching zone wherein the temperature dropped at a rate of at least $-350^{\circ} \mathrm{C} / \mathrm{sec}$ (Figure 1). A capped stainless steel tube with end perforations facilitated the introduction of after-fire air at the end of the isothermal zone. All of the experiments described herein were conducted with dry-injected sorbents and solid hydrocarbons with a nominal residence time of $1 \mathrm{~s}\left(\right.$ at $950^{\circ} \mathrm{C}$, bulk $\mathrm{Re}=3000$ and $50 \mu \mathrm{m}$ particle $\mathrm{Re}=2.1$ ) in the isothermal zone. Sorbent was conducted pneumatically through a water-cooled injector to the beginning of the isothermal zone. For all experiments, the background gas partial pressures were $12 \% \mathrm{CO}_{2}$, 
$3 \% \mathrm{O}_{2}, 2000$ ppm $\mathrm{SO}_{2}$ and 1000 ppm NO, balanced in $\mathrm{N}_{2}$. Although $\mathrm{NO}$ alone was introduced to the furnace, the total $\mathrm{NO}_{x}\left(\mathrm{NO}+\mathrm{NO}_{2}\right)$ was monitored at the furnace exhaust. Other species monitored at the furnace exhaust were $\mathrm{SO}_{2}, \mathrm{CO}$, and $\mathrm{CO}_{2}$.

\section{Experimental Results and Discussion}

Our goal was to determine the most efficient dual $\mathrm{SO}_{2}-\mathrm{NO}_{x}$ reduction 'blend' of carboxylic acid salts and auxiliary hydrocarbons. The hydrocarbons we considered were lignite, sucrose and poly(ethylene). Lignite was chosen because it is a practical fuel, it has a relatively high volatility and thus had a greater likelihood of complete burnout at the gas temperatures and residence time used, and it had been shown to produce $\mathrm{NH}_{3}$ under fuel-rich conditions (Chen, et al., 1982), thus the possibility of selective reactions between ammonia and $\mathrm{NO}_{x}$ near the $930^{\circ} \mathrm{C}$ temperature window of thermal de- $\mathrm{NO}_{x}$ (Lyon, 1975). Sucrose was chosen because it is an oxygen containing hydrocarbon and it was easy to work with experimentally; we used it to explore the effect of $\phi$ on $\mathrm{SO}_{2}-\mathrm{NO}_{x}$ reduction under conditions where most of the hydrocarbons were outside - not a chemical part of - the carboxylic acid salts. Poly(ethylene) was chosen because it is found in abundance in the municipal waste stream.

\section{1 $\mathrm{SO}_{2}-\mathrm{NO}_{x}$ Reduction by $\mathrm{CP}$ and Lignite}

\section{a. $\mathrm{SO}_{2}$ Reduction}

The reductions of $\mathrm{SO}_{2}$ and $\mathrm{NO}_{x}$ by $\mathrm{CP}, \mathrm{CP}$ plus lignite and $\mathrm{CP}$ plus $\mathrm{MgO}$ and lignite are presented in Table I. When $\mathrm{CP}$ was injected at a $\mathrm{Ca} / \mathrm{S}$ molar ratio $\leq 2.0$, the isothermal zone was fuel lean and the $\mathrm{SO}_{2}$ reduction was low. This may have been due to poor dispersion of a small amount of sorbent. When lignite was added to create fuel-rich conditions, $\mathrm{SO}_{2}$ capture changed 
Table I. $\mathrm{SO}_{2}-\mathrm{NO}_{x}$ Reduction by $\mathrm{CP}$ and Lignite at $1050^{\circ} \mathrm{C}$

\begin{tabular}{|c|c|c|c|c|c|}
\hline Sorbent & $(\mathrm{Ca}+\mathrm{Mg}) / \mathrm{S}$ & $\phi$ & $\begin{array}{c}\mathrm{SO}_{2} \text { Red. } \\
(\%)\end{array}$ & $\begin{array}{c}\text { Util. } \\
(\%)\end{array}$ & $\begin{array}{c}\mathrm{NO}_{x} \text { Red. } \\
(\%)\end{array}$ \\
\hline $\mathrm{CP}$ & 1.5 & 0.76 & 15 & 10 & 35 \\
$\mathrm{CP}+$ lignite & 1.8 & 2.3 & 15 & 8 & 80 \\
$\mathrm{CP}+\mathrm{MgO}+$ lignite & 2 & 2.4 & 30 & 15 & 70 \\
\hline
\end{tabular}

little. The addition of $\mathrm{MgO}$ doubled the $\mathrm{SO}_{2}$ reduction, although the total alkali earth to sulfur molar ratio was kept $\leq 2$.

Results obtained by Greene, et al., in experiments using combinations of different sorbents and secondary fuels showed sulfur captures of $15 \%$ or $22 \%$ using calcitic limestone at a $\mathrm{Ca} / \mathrm{S}$ molar ratio of 2 and propane as the secondary fuel. The difference in $\mathrm{SO}_{2}$ capture was due to the location of the sorbent injection. A $15 \% \mathrm{SO}_{2}$ capture was obtained when the sorbent was injected with the secondary fuel at a location in their furnace where the gas temperature was $\approx 1400^{\circ} \mathrm{C}$, whereas the $22 \% \mathrm{SO}_{2}$ capture occurred when the sorbent was injected with the after-fire air where the gas temperature was $\approx 1170^{\circ} \mathrm{C}$. The difference in $\mathrm{SO}_{2}$ capture was attributed to loss of stone reactivity at the higher injection temperature caused by sintering. The $\phi$ of the secondary fuel injection zone in that study was 1.1 and the residence times in the fuel-rich and after-fire zones were $0.4 \mathrm{sec}$. and $\approx 1 \mathrm{sec}$, , respectively. The fuel-rich zone was not isothermal, but had a cooling rate of $-575^{\circ} \mathrm{C}$ (the cooling rate of the after-fire zone was less than $-200^{\circ} \mathrm{C}$ ).

Greene, et al. (1985) concluded that $\mathrm{SO}_{2}$ reduction was relatively insensitive to a variation in $\phi$ between 0.9 and 1.4. However, their data showing $\mathrm{SO}_{2}$ and $\mathrm{H}_{2} \mathrm{~S}$ capture by calcitic limestone injected with the after-fire air at $\mathrm{Ca} / \mathrm{S}=2$ showed a clear, albeit slow, decrease in sulfur removal from $35 \%$ 
to $25 \%$ as $\phi$ of the fuel-rich zone increased from 0.9 to 1.4 . This trend is the same observed previously (Steciak, et al., 1994d) wherein, at an isothermal zone temperature of $950^{\circ} \mathrm{C}$, the reduction of $\mathrm{SO}_{2}$ measured downstream of the after-fire zone by carboxylic acid salts injected at $\mathrm{Ca} / \mathrm{S} \approx 2.8$ decreased from $75 \%$ at $\phi=0.5$ to $50 \%$ at $\phi=1.3$.

Another trend observed by Greene, et al. (1985) was the slow but measurable improvement of $\mathrm{H}_{2} \mathrm{~S}$ capture from $12 \%$ to $18 \%$ by calcitic limestone when both the sorbent and $\mathrm{H}_{2} \mathrm{~S}$ were injected with the secondary fuel at $\mathrm{Ca} / \mathrm{S}=1$ as $\phi$ increased from 0.9 to 1.4 . This will be mentioned again below with the change in $\mathrm{SO}_{2}$ capture by $\mathrm{CF}$ and sucrose as $\phi$ was varied.

Propane was the secondary fuel used by Greene, et al. (1985) to explore the dependence of sulfur capture on $\phi$.

\section{b. $\mathrm{NO}_{x}$ Reduction}

When $\mathrm{CP}$ was injected at a $\mathrm{Ca} / \mathrm{S}$ molar ratio $\leq 2.0$, the isothermal zone was fuel lean and the resulting $\mathrm{NO}_{x}$ reduction was low (Table I). This may have been due to poor dispersion of a small amount of sorbent. When lignite was added to create fuel-rich conditions, the $\mathrm{NO}_{x}$ reduction improved.

The $\mathrm{NO}_{x}$ reduction obtained by Greene, et al. (1985) using lignite injected at $1400^{\circ} \mathrm{C}$ was $50 \%$ at $\phi=1.1$ and a $\mathrm{NO}_{x}$ background of $\approx 600 \mathrm{ppm}$. When the partial pressure of $\mathrm{NO}_{x}$ was reduced to $\approx 200 \mathrm{ppm}$, no $\mathrm{NO}_{x}$ reduction was obtained by secondary fuel injection. In both cases, the $\mathrm{NO}_{x}$ reduction decreased with increasing $\phi$; for the experiments with $190 \mathrm{ppm} \mathrm{NO}_{x}, \mathrm{NO}_{x}$ production increased as $\phi$ decreased. The increase in $\mathrm{NO}_{x}$ production was attributed to the $1.11 \%$ nitrogen content of the lignite used in the experiments and the net production of $\mathrm{NO}_{x}$ above the background $190 \mathrm{ppm}$ occurred for all of the nitrogen-containing coals used as secondary fuels. The reduction of $\mathrm{NO}_{x}$ by lignite improved when the after-fire zone temperature was cooled from $\approx 1100^{\circ} \mathrm{C}$ to $\approx 900^{\circ} \mathrm{C} ;$ the improvement was attributed to selective reduction 
of NO by the amine radicals produced by lignite in the fuel-rich zone. When propane was injected as a secondary fuel, no net gain of $\mathrm{NO}_{x}$ was produced by this nitrogen-free fuel. At $\phi=1.1$ with a $\mathrm{NO}_{x}$ partial pressure of $\approx 600$ ppm, a maximum $\mathrm{NO}_{x}$ reduction of $55 \%$ occurred at an injection temperature of $1400^{\circ} \mathrm{C}$ and $70 \%$ at an injection temperature of $1560^{\circ} \mathrm{C}$. The $\mathrm{NO}_{x}$ reduction tended to decrease, albeit slowly, as $\phi$ increased. This trend is the opposite of that observed previously (Steciak, et al., 1994d) wherein, at an isothermal zone temperature of $950^{\circ} \mathrm{C}$, the reduction of $\mathrm{NO}_{x}$ measured downstream of the after-fire zone by carboxylic acid salts increased from $8 \%$ at $\phi=0.5$ to $90 \%$ at $\phi$ between 1.1 and 1.3 .

\section{2 $\mathrm{SO}_{2}-\mathrm{NO}_{x}$ Reduction by $\mathrm{CF}$ and Sucrose}

\section{a. $\mathrm{SO}_{2}$ Reduction}

The reductions of $\mathrm{SO}_{2}$ and $\mathrm{NO}_{x}$ by $\mathrm{CF}$ and sucrose are presented in Table II. When $\mathrm{CF}$ was injected at a $\mathrm{Ca} / \mathrm{S}$ molar ratio $\approx 1.0$ or $\approx 2.0$, the $\mathrm{SO}_{2}$ capture and calcium utilization (Figure 2) increased as $\phi$ of the isothermal zone increased.

This trend is the opposite of that obtained by calcium carboxylic acid salts wherein $\phi$ was increased by using salts with increasing amounts of hydrocarbons bonded to Ca (Steciak. et al., 1994d), i.e., CF, CA and CP. A physical explanation of why these opposite trends occur may rest on the ease of decomposition of the hydrocarbon.

When most of the organic was imbedded within and bonded with the salt, local fuel-rich clouds enveloped the particles as the organic components gasified. As the fraction of organic within the salt increased, longer times were needed for gasification and subsequent diffusion of $\mathrm{SO}_{2}$ to the calcined residues for heterogeneous sulfation.

When most of the organic was available outside the salt and decomposed 
Table II. $\mathrm{SO}_{2}-\mathrm{NO}_{x}$ Reduction by $\mathrm{CF}$ and Sucrose at $1000^{\circ} \mathrm{C}$

\begin{tabular}{|c|c|c|c|c|c|}
\hline$\frac{\mathrm{SO}_{2} \text { Red. }}{\mathrm{Ca}}$ & $\mathrm{Ca} / \mathrm{S}$ & $\phi$ & $\begin{array}{c}\text { Util. } \\
(\%)\end{array}$ & $\begin{array}{c}\mathrm{NO}_{x} \text { Red. } \\
(\%)\end{array}$ \\
\hline 1.25 & 1.25 & 0.81 & 8 & 6 & 15 \\
2.5 & 0.87 & 0.91 & 10 & 11 & 35 \\
3.0 & 1.09 & 1.1 & 28 & 26 & 70 \\
\hline 1.25 & 1.75 & 0.97 & 20 & 11 & - \\
1.6 & 2.16 & 1.16 & 68 & 31 & 65 \\
2.5 & 1.75 & 1.24 & 70 & 40 & 70 \\
\hline
\end{tabular}

separately, as for the experiments listed in Table II and plotted in Figure 2, diffusion of $\mathrm{SO}_{2}$ to the calcined residue was not hindered by an envelope cloud of gasifying hydrocarbons. Ca sulfation under fuel-rich conditions and fairly low temperatures may explain the role of the organic in $\mathrm{SO}_{2}$ removal observed by Steciak, et al. (1994b). Precalcined CMA was injected at $(\mathrm{Ca}+\mathrm{Mg}) / \mathrm{S}=6$ and $750^{\circ} \mathrm{C}$ and failed to remove more than $10 \%$ of $\mathrm{SO}_{2}$. Injection of the precalcined CMA in combination with sucrose to achieve $\phi=1.3$ caused the same amount of $\mathrm{SO}_{2}$ reduction as that obtained by raw $\mathrm{CMA}$ injected at the same $(\mathrm{Ca}+\mathrm{Mg}) / \mathrm{S}$ and $\phi$.

It is not clear why Greene, et al. (1985) observed improvement of $\mathrm{H}_{2} \mathrm{~S}$ capture by calcitic limestone when both the sorbent and $\mathrm{H}_{2} \mathrm{~S}$ were injected with the secondary fuel.

\section{b. $\mathrm{NO}_{x}$ Reduction}

When $\mathrm{CF}$ was injected at a $\mathrm{Ca} / \mathrm{S}$ molar ratio $\approx 1.0$ or $\approx 2.0$, the $\mathrm{NO}_{x}$ reduction (Figure 3 ) increased as $\phi$ of the isothermal zone increased. This was consistent with the trend obtained by calcium carboxylic acid salts wherein $\phi$ was increased by using salts with increasing amounts of hydrocarbons bonded 


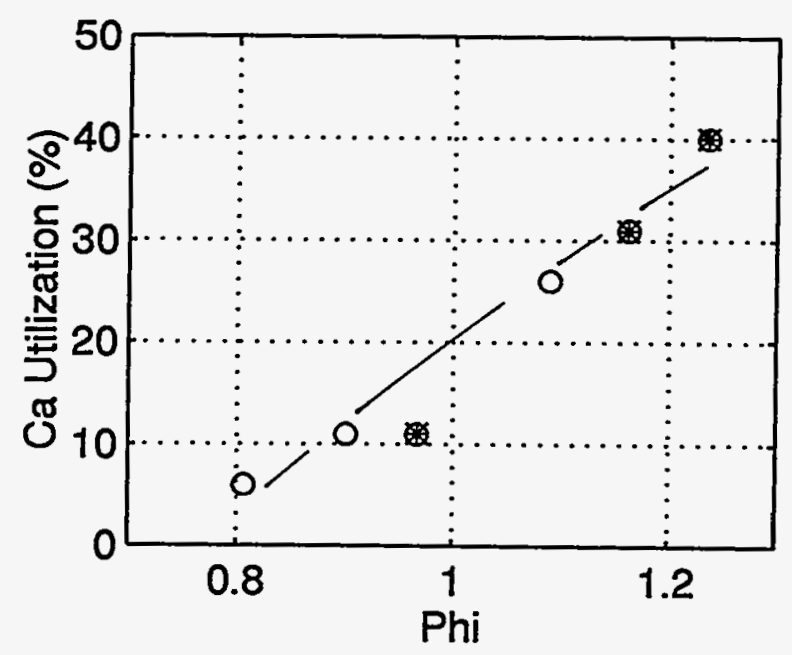

Figure 2: Ca utilization by $\mathrm{CF}$ and sucrose as a function of $\phi$ at $1000^{\circ} \mathrm{C}$ 


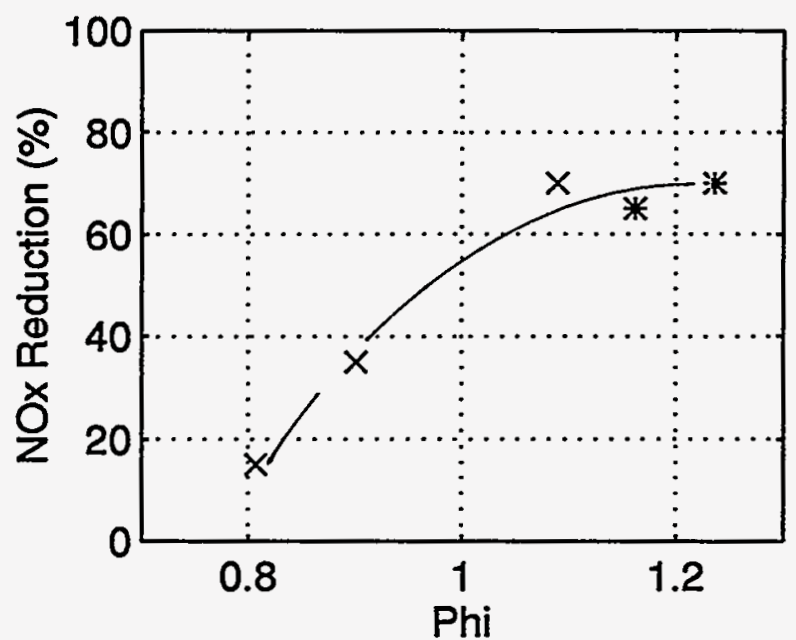

Figure 3: $\mathrm{NO}_{x}$ reduction by $\mathrm{CF}$ and sucrose as a function of $\phi$ at $1000^{\circ} \mathrm{C}$ 
Table III. $\mathrm{SO}_{2}-\mathrm{NO}_{x}$ Reduction by $\mathrm{CF}$ and Poly(ethylene) at $1000^{\circ} \mathrm{C}$

\begin{tabular}{|c|c|c|c|c|c|c|}
\hline Zone & $\mathrm{C} / \mathrm{Ca}$ & $\mathrm{Ca} / \mathrm{S}$ & $\begin{array}{c}\text { Iso. Zone } \\
\phi\end{array}$ & $\begin{array}{c}\mathrm{SO}_{2} \text { Red. } \\
(\%)\end{array}$ & $\begin{array}{c}\text { Util. } \\
(\%)\end{array}$ & $\begin{array}{c}\mathrm{NO}_{x} \text { Red. } \\
(\%)\end{array}$ \\
\hline Isotherm. & 12 & 2.2 & 2.0 & 98 & $45+$ & 97 \\
After-fire & 12 & 2.2 & 2.0 & 98 & $45+$ & 89 \\
\hline
\end{tabular}

to $\mathrm{Ca}$ (Steciak. et al., 1994d), i.e., $\mathrm{CF}, \mathrm{CA}$ and $\mathrm{CP}$. While some $\mathrm{NO}_{x}$ reduction reactions are catalyzed by $\mathrm{CaO}$ (Steciak, et al. (1994a), most selective and non-selective reactions occur in the gas phase and would not be affected by diffusion through local fuel-rich clouds. The trend of improving $\mathrm{NO}_{x}$ reduction with increasing $\phi$ in Figure 3 was the opposite of that observed by Greene, et al. (1985). The explanation for the difference may lie in the significant difference in gas temperature between the experiments of Greene, et al. (1985) and Figure 3 (1400 vs. $1000{ }^{\circ} \mathrm{C}$, respectively). The lower temperature reactions may allow for the selective reduction of $\mathrm{NO}$ by $\mathrm{NH}_{3}$ formed during the fuelrich decomposition of the organics. Some $\mathrm{NH}_{3}$ was measured in the isothermal reaction zone during $\mathrm{NO}_{x}$ reduction by $\mathrm{CP}$ (Steciak, et al. (1994)) and nearly all of it oxidized to $\mathrm{NO}_{x}$ in the after-fire air zone.

\section{3 $\mathrm{SO}_{2}-\mathrm{NO}_{x}$ Reduction by $\mathrm{CF}$ and Poly(ethylene)}

\section{a. $\mathrm{SO}_{2}$ Reduction}

Nearly $100 \%$ reduction of $\mathrm{SO}_{2}$ was obtained by a blend of $\mathrm{CF}$ and poly(ethylene) at $1000^{\circ} \mathrm{C}$ at a $\mathrm{Ca} / \mathrm{S}=2.2, \phi=2.0$ and $\mathrm{C} / \mathrm{Ca}=12$ (or one mole of $\left[-\mathrm{CH}_{2}-\right]_{10}$ per mole of $\mathrm{Ca}$ ), as listed in Table III. The addition of after-fire air had no effect on $\mathrm{SO}_{2}$ reduction.

b. $\mathrm{NO}_{x}$ Reduction 
Nearly $100 \%$ reduction of $\mathrm{NO}_{x}$ was obtained by the same blend of $\mathrm{CF}$ and poly(ethylene), as listed in Table III. The addition of after-fire air lowered $\mathrm{NO}_{2}$ reduction to $89 \%$, suggesting that $\mathrm{NH}_{3}$ or $\mathrm{HCN}$ products from the fuel-rich reaction zone were oxidized back to $\mathrm{NO}_{x}$.

The excellent $\mathrm{SO}_{2}-\mathrm{NO}_{x}$ reduction demonstrated by this blend of carboxylic acid salt and plastic is intriguing and warrants the full investigation of blends of different carboxylic acid salts and other plastics.

\section{Conclusions and Recommendations}

1. Simple calculations of operating costs suggest that application of the carboxylic acid salts for dual $\mathrm{SO}_{2}-\mathrm{NO}_{x}$ reduction could become competitive if their price is lowered significantly, if the utilization of the alkali earth metals is optimized, and if part of the expensive carboxylic acids could be replaced with less expensive hydrocarbons such as lignite or even waste plastics.

2. The reduction of $\mathrm{SO}_{2}$ by combinations of calcium carboxylic acid salts and hydrocarbons injected into the reaction zone increased as $\phi$ increased. This trend opposed that found previously by Steciak, et al. (1994d) wherein the reduction of $\mathrm{SO}_{2}$ by carbon carboxylic acid salts decreased as $\phi$ increased. The physical explanation may rest on the ease of decomposition of the hydrocarbon.

When most of the organic was bonded within the salt, local fuel-rich clouds that could be extremely fuel-rich enveloped the particles as the organic components gasified and opposed the diffusion of $\mathrm{SO}_{2}$ to the particle. When most of the organic was available outside the salt and decomposed separately, diffusion of $\mathrm{SO}_{2}$ to the calcined residue was not hindered by an envelope cloud of gasifying hydrocarbons. 
3. The reduction of $\mathrm{NO}_{x}$ by calcium carboxylic acid salts increased as $\phi$ increased regardless of whether the increase in $\phi$ was due to an increase in hydrocarbons bonded to the $\mathrm{Ca}$ or injected into the reaction zone. This trend suggests that selective reduction of NO could occur in the by amine radicals that were produced in the fuel-rich zone as the hydrocarbons decomposed. This selective reduction would be in addition to the nonselective reduction of $\mathrm{NO}_{x}$ by $\mathrm{HC}$ radicals.

4. Excellent $\mathrm{SO}_{2}-\mathrm{NO}_{x}$ reduction was obtained by a dry-injected blend of $\mathrm{CF}$ and poly(ethylene). Further investigation of carboxylic acid salt-plastic blends are warranted.

5. Dual $\mathrm{SO}_{2}-\mathrm{NO}_{x}$ reduction by combinations of wet-sprayed carboxylic acid salts and different plastics should be investigated. Wet-spraying achieves high $\mathrm{Ca}$ utilization for efficient $\mathrm{SO}_{2}$ removal. The use of waste plastics as sacrificial hydrocarbons for the reduction of $\mathrm{NO}_{x}$ diverts significant amounts of material from landfills. The presence of $\mathrm{Ca}$ in the reaction zone may also remove $\mathrm{Cl}$, a decomposition product of chlorinated hydrocarbons, in the form of $\mathrm{CaCl}_{2}$. The combination of wet-sprayed carboxylic acid salts and waste plastics may be the most economical and advantageous scheme for $\mathrm{SO}_{2}-\mathrm{NO}_{x}$ reduction, providing that the cost of the carboxylic acid salts can be significantly reduced and the plastics can be shredded or ground to facilitate quick decomposition in the reaction zone.

\section{Acknowledgments}

This work was supported by U.S. Dept. of Energy University Grant DE-FG2292PC92535. 


\section{References}

- Chen, S. L., Clark, W. D., Heap, M. P., Pershing, D. W., and Seeker, W. D. (1982) $\mathrm{NO}_{x}$ Reduction by Reburning With Gas and Coal - Bench Scale Studies. Proceedings of the Joint Symposium on Stationary Combustion $N O_{x}$ Control.

- Doughty, R. C., and Collazo-Lopez, H. (1987). Reduction of Organochlorine Emissions from Municipal and Hazardous Waste Incinerators. Environmental Science and Technology, 21, 602 - 604.

- Greene, S. B., Chen, S. L., Clark, W. D., Heap, M. P., Pershing, D. W., and Seeker, W. R. (1985) Bench-Scale Process Evaluation of Reburning and Sorbent Injection for In-furnace $\mathrm{NO}_{x} / \mathrm{SO}_{x}$ Reduction. Environmental Protection Agency, Research Triangle Park, NC, EPA/600/7-85/012.

- Lyon, R. P. (1975) Method for the Reduction of the Concentration of NO in Combustion Effluents Using Ammonia. U.S. Patent No. 3,900,554.

- Snow, M. J. H., Longwell, J. P., and Sarofim, A. F. (1988) Direct Sulfation of Calcium Carbonate. Ind. Eng. Chem. Res. 27, 268-273.

- Steciak, J., Zhu, W., Levendis, Y. A., and Wise, D. L. (1994a) The Effectiveness of Calcium (Magnesium) Acetate and Calcium Benzoate as $\mathrm{NO}_{x}$ Reduction Agents in Coal Combustion. Accepted for publication in Combustion Science and Technology.

- Steciak, J., Levendis, Y. A., and Wise, D. L. (1994b) The Effectiveness of Calcium Magnesium Acetate as a Dual $\mathrm{SO}_{2}-\mathrm{NO}_{x}$ Emission Control Agent. Submitted for publication.

- Steciak, J., Levendis, Y. A., Wise, D. L., and Simons, G. A. (1994c) Reduction of Combustion-Generated $\mathrm{SO}_{2}-\mathrm{NO}_{x}$ by Fine Mists of CMA. 19th 
International Conference on Coal Utilization and Fuel Systems, Clearwater, Florida.

- Steciak, J. Levendis, Y. A., Wise, D. L., and Simons, G. A. (1994d) Dual $\mathrm{SO}_{2}-\mathrm{NO}_{x}$ Reduction be Calcium Salts of Carboxylic Acids. Submitted for publication.

- Tullin, C., and Ljungström, E. (1989) Reaction Between Calcium Carbonate and Sulfur Dioxide. Energy and Fuels. 3, 284 - 287.

- Wendt, J. O. L, Sternling, C. V., and Matovich, M. A. (1973) Reduction of Sulfur Trioxide and Nitrogen Oxides by Secondary Fuel Injection. Fourteenth Symposium (International) on Combustion. pp. 897 - 904, The Combustion Institute, Pittsburgh.

- Wheatly, L., Levendis, Y. A., and Vouros, P. (1993) Exploratory Study on the Combustion and PAH Emissions of Selected Municipal Waste Plastics. Environmental Science and Technology. 27, 2885 - 2895.

- Yagiela, A. S., Maringo, G. J., Newell, R. J., and Farzan, H. (1991) Update of Coal Reburning Technology for Reducing $\mathrm{NO}_{x}$ in Cyclone Boilers. American Power Conference. 
CHAPTER 7. 


\section{Overall Summary}

A study was conducted to determine the efficacy of carboxylic calcium and magnesium salts for the simultaneous removal of $\mathrm{SO}_{2}$ and $\mathrm{NO}_{x}$ in oxygen-lean atmospheres. Experiments were performed in a high-temperature, laboratoryscale furnace which simulated the post-flame environment of a coal-fired boiler by providing similar temperatures and partial pressures of $\mathrm{SO}_{2}, \mathrm{NO}_{x}, \mathrm{CO}_{2}$ and $\mathrm{O}_{2}$. The salts tested included calcium magnesium acetate (CMA, Ca $\left.\mathrm{Mg}_{2}\left(\mathrm{CH}_{2} \mathrm{COOH}\right)_{6}\right)$, calcium acetate $\left(\mathrm{CA}, \mathrm{Ca}\left(\mathrm{CH}_{2} \mathrm{COOH}\right)_{2}\right)$, magnesium acetate $\left(\mathrm{MA}, \mathrm{Mg}\left(\mathrm{CH}_{2} \mathrm{COOH}\right)_{2}\right)$, calcium formate $\left(\mathrm{CF}, \mathrm{Ca}(\mathrm{COOH})_{2}\right)$, calcium propionate $\left(\mathrm{CP}, \mathrm{Ca}\left(\mathrm{CH}_{2} \mathrm{CH}_{2} \mathrm{COOH}\right)_{2}\right)$, and calcium benzoate (CB, $\left.\mathrm{Ca}\left(\mathrm{C}_{7} \mathrm{H}_{5} \mathrm{O}_{2}\right)_{2}\right)$.

When injected into a hot environment, the salts calcined and formed highly porous cenospheres. Residual $\mathrm{MgO}$ and/or $\mathrm{CaCO}_{3}$ and $\mathrm{CaO}$ reacted heterogeneously with $\mathrm{SO}_{2}$ to form $\mathrm{MgSO}_{4}$ and/or $\mathrm{CaCO}_{4}$. The organic components gasified and reduced $\mathrm{NO}_{2}$ to $\mathrm{N}_{2}$ effectively in moderately fuel-rich atmospheres.

On a $\mathrm{Ca} / \mathrm{S}$ molar ratio basis, CMA was found to be the most effective dual $\mathrm{SO}_{2}-\mathrm{NO}_{x}$ reduction agent. Dry-injected CMA particles at a $\mathrm{Ca} / \mathrm{S}$ ratio of 2 and bulk equivalence ratio $\phi$ of 1.3 removed $90 \%$ of $\mathrm{SO}_{2}$ and $\mathrm{NO}_{x}$ at gas temperatures $\geq 950^{\circ} \mathrm{C}$ in atmospheres containing $3 \% \mathrm{O}_{2}, 12 \% \mathrm{CO}_{2}, 2000 \mathrm{ppm}$ $\mathrm{SO}_{2}$, and $1000 \mathrm{ppm} \mathrm{NO}_{x}$ during a $\approx 1$ s residence time in the isothermal zone of the furnace.

The role of $\mathrm{Mg}$ during rapidly quenched experiments at gas temperatures $\leq 950^{\circ} \mathrm{C}$ was quantified. In the isothermal zone, on a per-mole basis, Ca contributed between 20 and $30 \%$, and $\mathrm{Mg}$ contributed between 10 and $15 \%$, to $\mathrm{SO}_{2}$ reduction during a $4 \mathrm{~s}$ residence time. $\mathrm{Ca}$ was essentially inert in the furnace quenching zone, while $\mathrm{Mg}$ continued to sorb $\mathrm{SO}_{2}$ as the gas temperature cooled at a rate of $-130^{\circ} \mathrm{C} / \mathrm{sec}$. Hence, the removal of $\mathrm{SO}_{2}$ by CMA could continue for nearly the entire residence time of emissions in the exhaust stream 
of a power plant.

It can be expected that isothermal zone temperatures $950^{\circ} \mathrm{C}$ - including temperatures above $1270^{\circ} \mathrm{C}$, the stability limit for $\mathrm{CaSO}_{4}$ - could lead to temperatures that are high enough to favor Ca sulfation kinetics in the region of the furnace where gas temperature cooled at a rate of $-130^{\circ} \mathrm{C} / \mathrm{sec}$. Essentially no $\mathrm{SO}_{2}$ was emitted during the combustion of CMA-treated pulverized coal in air at furnace gas temperatures of $1180^{\circ} \mathrm{C}$. During these experiments, the temperature of the volatile and char phase of coal particles treated with CMA were 2130 and $1730^{\circ} \mathrm{C}$, respectively (Appendix I).

At gas temperatures below $800^{\circ} \mathrm{C}$, the organic components of the salts did not completely gasify during the residence time in the furnace. Ca was transformed to $\mathrm{CaCO}_{3}$ and/or bound organically; the organically bound $\mathrm{Ca}$ would be unavailable for reaction with $\mathrm{SO}_{2}$. At temperatures between 900 to $1150^{\circ} \mathrm{C}, \mathrm{Ca}$ was found in the forms of $\mathrm{CaCO}_{3}$ and/or $\mathrm{CaO}$. The composition of the calcined salts and the availability of $\mathrm{Ca}$ was used to interpret the results of a cenosphere sulfation model. The sulfation kinetics of $\mathrm{Ca}$-containing residues were found to be bounded by those of pure $\mathrm{CaO}$ and pure $\mathrm{CaCO}_{3}$.

The high solubility of the salts, compared with slaked lime $\left(\mathrm{Ca}(\mathrm{OH})_{2}\right)$ or limestone $\left(\mathrm{CaCO}_{3}\right)$ (e.g., $30 \mathrm{~g} / 100 \mathrm{cc}$ for CMA vs. $0.85 \mathrm{~g} / 100 \mathrm{cc}$ for slaked lime and $0.0015 \mathrm{~g} / 100 \mathrm{cc}$ for limestone) makes them excellent candidates for wet injection. Fine mists of CMA, produced with an aerosol generator and sprayed in the furnace at temperatures between 850 and $1050^{\circ} \mathrm{C}$, removed $90 \%$ of $\mathrm{SO}_{2}$ at a $\mathrm{Ca} / \mathrm{S}$ molar ratio of 1 , about half of the amount used in the dry injection experiments. About $15 \%$ of the $\mathrm{SO}_{2}$ was scrubbed by water alone. When CMA was sprayed at a $\mathrm{Ca} / \mathrm{S}$ ratio of 1 , the $\mathrm{NO}_{x}$ reduction chemistry was not affected by the presence of water, i.e., the same reduction efficiency was achieved as with dry injection (25-30\%).

Because the efficiency of $\mathrm{NO}_{x}$ removal by secondary fuel injection is a func- 
tion of the initial partial pressure of NO, future experiments should determine the $\mathrm{SO}_{2}-\mathrm{NO}_{x}$ reduction efficacy of the carboxylic acid salts when the initial NO partial pressure is $300 \mathrm{ppm}$ and below.

Additional research is needed to improve the efficiency and reduce the cost of the relatively expensive carboxylic acid salts as dual $\mathrm{SO}_{2}-\mathrm{NO}_{x}$ reduction agents. One suggestion is combining wet injection of the salts (with a $\mathrm{Ca}$ utilization of - or perhaps even higher than -65\%) with less expensive reburning fuels such as lignite or even polymers such as polyethylene which could be extracted from the municipal waste stream. 


\section{APPENDIX II.}




\section{Determination of the Bulk Equivalence Ratio, $\phi$}

The bulk or average equivalence ratio, $\phi$, is defined as the ratio of the actual fuel-to-oxidant ratio to the stoichiometric fuel-to-oxidant ratio. If $\phi$ is less than one, more than enough oxidant is present to react with all the fuel and the reaction conditions are termed fuel-lean. If $\phi$ is equal to one, exactly enough fuel and oxidant are present for the reactions to go to completion. This condition is called stoichiometric. When $\phi$ is greater than one, more than enough fuel is present to react with all the oxidant, and this condition is called fuel-rich. It is important to note that the bulk $\phi$ is the same as the actual $\phi$ in a reactor only if the reactants are perfectly mixed. Usually this is not the case and pockets of fuel-rich and fuel-lean conditions can exists regardless of the bulk $\phi$. Nonetheless, the calculation of $\phi$ is useful practically since it indicates trends and can guide burner design to control emissions.

In the furnace used for the experiments with dual $\mathrm{SO}_{2}-\mathrm{NO}_{x}$ reducing agents, the sorbents were either dry- or wet-injected. In both cases, the sorbents were injected directly into the hot isothermal reaction zone (via pneumatic transport through a water-cooled injector) which contained a mixture of $\mathrm{SO}_{2}$ and NO. The sorbents mixed with the gases in the furnace. Each particle or droplet briefly sustained an envelope of gasifying hydrocarbons, creating fuel-rich conditions within the envelope. When gasification was complete, $\mathrm{SO}_{2}$ had to diffuse into the interior pores of the resulting cenospheres. During the sulfation of cenospheres containing $\mathrm{CaCO}_{3}, \mathrm{CO}_{2}$ was released as a product and had to diffuse out of the interior pores. Even when a blend of $\mathrm{SO}_{2}$ and $\mathrm{NO}$ was used to transport the sorbents to the isothermal zone in order to pre-mix the sorbents and the gases, considerable local diffusion and mixing occurred because of gasification and sulfation. Hence, the value of calculating $\phi$ was 
simply to observe trends and note changes in sulfation and $\mathrm{NO}_{x}$ reduction efficiency as overall conditions change from fuel-lean to fuel-rich.

Oxygen was present in most of the sorbents as well as in $\mathrm{SO}_{2}, \mathrm{NO}$, and the background gas. For CMA injected at a molar $\mathrm{Ca} / \mathrm{S}$ ratio of 2 in an atmosphere containing $2000 \mathrm{ppm} \mathrm{SO}, 1000 \mathrm{ppm} \mathrm{NO}$ and unlimited $\mathrm{O}_{2}$, the overall stoichiometry to reduce $\mathrm{NO}$ to $\mathrm{N}_{2}$ and form $\mathrm{CaSO}_{4}$ from $\mathrm{SO}_{2}$ and $\mathrm{Ca}$ was described by the following global reaction:

$\mathrm{CaMg}_{2}\left(\mathrm{CH}_{2} \mathrm{COOH}\right)_{6}+\frac{1}{2} \mathrm{SO}_{2}+\frac{1}{4} \mathrm{NO}+12 \frac{1}{8} \mathrm{O}_{2} \rightarrow \frac{1}{2} \mathrm{CaSO}_{4}+\frac{1}{2} \mathrm{CaO}+2 \mathrm{MgO}$ $+12 \mathrm{CO}_{2}+9 \mathrm{H}_{2} \mathrm{O}+\frac{1}{2} \mathrm{~N}_{2}$

For each mole of fuel (CMA), the number of moles of oxygen in the reactants was $6+\frac{1}{2}+\frac{1}{8}+12 \frac{1}{8}=18 \frac{3}{4}$. Hence, the stoichiometric fuel-to-air ratio was $f_{s}=\frac{M W_{C M A}}{18 \frac{3}{4} M W_{O_{2}}}=0.737$, i.e., one gram of $\mathrm{O}_{2}$ was needed with each $0.737 \mathrm{~g}$ of CMA to completely convert $\mathrm{SO}_{2}$ to $\mathrm{CaSO}_{4}$ and $\mathrm{NO}$ to $\mathrm{N}_{2}$ - with unreacted $\mathrm{CaO}$ and $\mathrm{MgO}$ left over.

The actual fuel-to-oxidant ratio in the isothermal reaction zone was quite different. The molar flow of $\mathrm{O}_{2}$ in the sorbent, $\mathrm{SO}_{2}, \mathrm{NO}$ and the background gas were determined first. For each gas, its molar inflow was

$$
p_{g a s} \dot{V} \frac{1}{22.4 l i t / m o l} \frac{273}{295}
$$

where $p_{\text {gas }}$ was the partial pressure of the gas (in $\mathrm{N}_{2}$ ) and $\dot{V}$ its volumetric flow rate. Because $\mathrm{SO}_{2}$ and $\mathrm{NO}$ were introduced into the furnace at a volumetric rate of $1 \mathrm{lpm}$ at room temperature, and $\mathrm{O}_{2}$ at a rate of $2 \mathrm{lpm}$, the partial pressure of all of the gases at the furnace inlet was higher than that in the furnace because of dilution to achieve the desired final concentration. For $\mathrm{CMA}$ injected at a $\mathrm{Ca} / \mathrm{S}$ molar ratio of 2 in an atmosphere containing 2000 ppm $\mathrm{SO}_{2}, 1000 \mathrm{ppm} \mathrm{NO}$ and $3 \% \mathrm{O}_{2}$, the inlet partial pressures were $6000 \mathrm{ppm}$ $\mathrm{SO}_{2}, 3000 \mathrm{ppm} \mathrm{NO}$, and $4.5 \% \mathrm{O}_{2}$. Hence, the total mass inflow of $\mathrm{O}_{2}$ was

$$
\dot{m}_{O_{2}}=\left(\dot{n}_{S_{2}}+\frac{1}{2} \dot{n} N O+\dot{n}_{O_{2}}+\dot{n}_{O_{2} i n C M A}\right) \cdot M W_{O_{2}}
$$


where $\dot{n}$ is the molar flow rate and

$$
\dot{n}_{\mathrm{O}_{2} \text { inCMA }}=6 \cdot \mathrm{Ca} / \mathrm{S} \cdot \dot{n}_{\mathrm{SO}_{2}}
$$

since there were 6 moles of $\mathrm{O}_{2}$ for each mole of CMA. The mass inflow of CMA was

$$
\dot{m}_{C M A}=M W_{C M A} \cdot C a / S \cdot \dot{n}_{S O_{2}}
$$

This resulted in an actual fuel-to-oxidant ratio of $f_{a}=0.935$, i.e., $0.935 \mathrm{~g}$ of CMA was provided with each gram of $\mathrm{O}_{2}$ in an attempt to convert $\mathrm{SO}_{2}$ to $\mathrm{CaSO}_{4}$ and $\mathrm{NO}$ to $\mathrm{N}_{2}$. Whether or not this amount of $\mathrm{O}_{2}$ was sufficient was determined by the equivalence ratio:

$\phi=\frac{f_{a}}{f_{s}}=\frac{0.935}{0.737}=1.27$

Here, $\phi>1$; hence, the overall reaction conditions were fuel-rich and insufficient $\mathrm{O}_{2}$ was provided for the complete conversion of the reactants to the products listed in $\mathrm{R} 1$. In the experiments, fuel-rich conditions resulted in copious formation of $\mathrm{CO}$ and trace concentrations of $\mathrm{H}_{2} \mathrm{~S}, \mathrm{HCN}$ and $\mathrm{NH}_{3}$. The addition of afterfire air oxidized $\mathrm{CO}$ to $\mathrm{CO}_{2}, \mathrm{H}_{2} \mathrm{~S}$ to $\mathrm{SO}_{2}$, and $\mathrm{HCN}$ and $\mathrm{NH}_{3}$ to $\mathrm{NO}$ and thus lowered the overall $\mathrm{SO}_{2}-\mathrm{NO}_{x}$ reduction efficiency. The loss of dual $\mathrm{SO}_{2}-\mathrm{NO}_{x}$ reduction efficiency was significant for $\phi>1.3$ (Chapter 5).

The bulk equivalence ratios for the other sorbents and different $\mathrm{Ca} / \mathrm{S}$ molar ratios were calculated in a similar manner.

\section{Notation}

$\begin{array}{cll}\text { SYMBOL } & \text { DESCRIPTION } & \text { UNITS } \\ f_{a} & \text { actual fuel-to-oxidant ratio } & - \\ f_{s} & \text { stoichiometric fuel-to-oxidant ratio } & - \\ M W & \text { molecular weight } & \frac{g}{m o l} \\ \dot{m} & \text { mass flow rate } & \frac{g}{m i n} \\ \dot{n} & \text { molar flow rate } & \frac{m o l}{m i n} \\ p & \text { partial pressure } & \text { atm }\end{array}$




$\begin{array}{llll}\dot{V} & \text { volumetric flow rate } & \frac{\text { lit }}{\min } \\ \phi & \text { equivalence ratio } & \cdot & -\end{array}$


APPENDIX III. 


\section{Chemical Thermodynamics and Chemical Kinetics Calculations}

Whether or not a chemical reaction was thermodynamically possible over a particular temperature range was determined by calculating the change in the Gibbs free energy per mole, $\Delta G$ (or the chemical potential), for that reaction. For an individual species,

$$
\Delta G_{f}=h_{o}+\Delta h-T \Delta s
$$

where $h_{o}$ is the enthalpy of formation at $298 \mathrm{~K}, \Delta h$ is the enthalpy change between $298 \mathrm{~K}$ and temperature $\mathrm{T}$, and $\mathrm{s}$ is the absolute entropy. Occasionally, thermodynamic data sources - especially ones published in recent years - tabulated $\Delta G_{f}$ directly, but Eqn. 1 was used most frequently. The thermodynamic data sources used are listed below. For a particular chemical reaction

$$
\nu_{A}[A]+\nu_{B}[B] \longrightarrow \nu_{C}[C]+\nu_{D}[D]
$$

where $\nu_{i}$ are the stoichiometric coefficients and [i] denotes concentration of species $i$, the change in Gibbs free energy is

$$
\Delta G=\Sigma \nu_{p} \Delta G_{f, p}-\Sigma \nu_{r} \Delta G_{f, r}=\nu_{C} \Delta G_{f, C}+\nu_{D} \Delta G_{f, D}-\left(\nu_{A} \Delta G_{f, A}+\nu_{B} \Delta G_{f, B}\right)
$$

If $\Delta G$ is negative, the reaction is spontaneous at all $\mathrm{T}$. Also,

$$
\Delta G=-R T \ln (K(T))
$$

where $R$ is the ideal gas constant and $K(T)$ is the equilibrium constant defined by

$$
K(T)=\frac{y_{C}^{\nu_{C}} y_{D}^{\nu_{D}}}{y_{A}^{\nu_{A}} y_{B}^{\nu_{B}}} \frac{p}{p_{r e f}}{ }^{\nu_{C}+\nu_{D}-\nu_{A}-\nu_{B}}
$$

where $y_{i}$ are the species mole fractions and $p$ is pressure. Hence, the equilibrium constant can be calculated if $\Delta G$ is known. It also follows that, if 
$\log _{10}(K(T))$ is positive, the reaction is spontaneous. The Gibbs free energy change was calculated using tabulated thermodynamic data from 700 to $1700 \mathrm{~K}$ $\left(427-1427^{\circ} \mathrm{C}\right)$ for a number of reactions in Chapters 2 and 5.

Knowledge of the rate of reaction was needed to determine how fast a reaction would occur, given that it was spontaneous over the temperature range of interest. Kinetics and thermodynamics are linked by the equilibrium constant and the rate constants for a reaction:

$$
K(T)=\frac{k_{f}}{k_{r}}
$$

where $k$ is the rate constant, the subscripts $f$ and $r$ refer to the forward and reverse reactions, respectively, and $k$ is assumed to follow the Arrhenius equation:

$$
k=A \cdot \exp \left(-\frac{E_{a}}{R T}\right)
$$

where $A$ is the pre-exponential factor and $E_{a}$ is the activation energy. Thus, if the forward rate constant is known, the reverse constant can be calculated, and vice versa.

For example, the reaction rate constant for the direct sulfation of $\mathrm{CaCO}_{3}$ :

$$
\mathrm{CaCO}_{3}+\frac{1}{2} \mathrm{O}_{2}+\mathrm{SO}_{2} \longrightarrow \mathrm{CaSO}_{4}+\mathrm{CO}_{2}
$$

was provided by Snow, et al. (1988) as

$$
k_{f}=71.8 \cdot \exp \left(-\frac{15,300}{1.987 T}\right) \frac{\mathrm{cm}}{\mathrm{sec}}
$$

To convert this to the same scale used in the sulfation model (Simons, et al., 1987) used in Chapter 5, the pre-exponential factor 71.8 was modified by

$$
A^{\prime}=71.8 \frac{M_{\mathrm{SO}_{2}}}{R T p_{\mathrm{SO}_{2}}} \frac{\mathrm{g}}{\mathrm{cm}^{2} \cdot \mathrm{sec} \cdot \mathrm{atm}}
$$

so that

$$
k^{\prime}=71.8 \frac{M W_{\mathrm{SO}_{2}}}{R T p_{\mathrm{SO}_{2}}} \cdot \exp \left(-\frac{15,300}{1.987 T}\right)
$$


A straight line fit to a plot of $\ln \left(k^{\prime}\right)$ vs. $1 / \mathrm{T}$ yielded a new effective preexponential factor $\left(A^{\prime \prime}=10.76\right)$ and activation energy $\left(E_{a}^{\prime}=-13,440 \mathrm{cal} / \mathrm{mol}\right)$ that were used in the sulfation model. The reverse reaction rate constant was calculated using Eqn. 6.

\section{REFERENCES}

- Simons, G. A., Garman, A. R., and Boni, A. A., "The Kinetic Rate of $\mathrm{SO}_{2}$ Sorption by $\mathrm{CaO}, "$ AIChE Journal, 33, 211, 1987.

- Snow, M. J. H., Longwell, J. P., and Sarofim, A. F., "Direct Sulfation of Calcium Carbonate," Industrial and Engineering Chemical Research, 27, 268, 1988.

\section{THERMODYNAMIC DATA SOURCES}

- Barin, I., "Thermochemical Data of Pure Substances," VCH Publishers, NY, NY, 1989.

- Chase, et al., "JANAF Thermochemical Tables," J. Phys. Chem. Ref. Data, 14, Suppl. 1, 1985.

- Gurvich, L. V., Veyts, I. V., Alcock, C. B., and Iorish, V. S., Eds., Thermodynamic Properties of Individual Substances, Fourth Edition, Hemisphere, NY, NY, 1991.

- Kee, R. J., Rupley, F. M., and Miller, J. A., "The Chemkin Thermodynamic Data Base," SAND87-8215B, Sandia National Laboratories, Albuquerque, NM, 1990.

- Lide, D. R., Ed., CRC Handbook of Chemistry and Physics, 73rd Edition, CRC Press, Ann Arbor, MI, 1992-93. 
- Yaws, C. L., Thermodynamic and Physical Property Data, Gulf Publishing Company, London, 1992.

\section{Notation}

$\begin{array}{cll}\text { SYMBOL } & \text { DESCRIPTION } & \text { UNITS } \\ A & \text { pre-exponential factor } & \text { varies } \\ E_{a} & \text { activation energy } & \frac{c a l}{m o l} \\ \Delta G & \text { Gibbs free energy change } & \frac{k J}{k m o l} \\ h_{o} & \text { enthalpy of formation } & \frac{k J}{k m o l} \\ \Delta h & \text { enthalpy } & \frac{k J}{k m o l} \\ k & \text { reaction rate constant } & \text { varies } \\ K(T) & \text { equilibrium constant } & - \\ p & \text { pressure } & \text { atm } \\ R & \text { ideal gas constant } & 0.080206 \frac{\mathrm{atm} \cdot \mathrm{lit}}{\mathrm{mol} \cdot K} \text { or } 1.987 \frac{\mathrm{cal}}{\mathrm{mol} \cdot K} \\ s & \text { absolute entropy } & \frac{k J}{k m o l \cdot K} \\ T & \text { temperature } & K \\ y & \text { mole fraction } & - \\ \nu & \text { stoichiometric coefficient } & \mathrm{mol}\end{array}$

